Article

\title{
Impact of Proton Beam Irradiation on the Growth and Biochemical Indexes of Barley (Hordeum vulgare L.) Seedlings Grown under Salt Stress
}

\author{
Lacramioara Oprica ${ }^{1}$, Marius-Nicusor Grigore ${ }^{1, *(\mathbb{D})}$, Iulia Caraciuc ${ }^{2}$, Daniela Gherghel ${ }^{3, *}$, \\ Cosmin-Teodor Mihai ${ }^{3,4}$ (D) and Gabriela Vochita ${ }^{3}$ (D) \\ 1 Faculty of Biology, Alexandru Ioan Cuza University, 20A Carol I Bd., 700506 Iasi, Romania; \\ iasilacra@yahoo.com \\ 2 National Institute for Research and Development in Electrical Engineering ICPE-CA, 313 Splaiul Unirii, \\ District 3, 030138 Bucharest, Romania; iulia.caraciuc@icpe-ca.ro \\ 3 Institute of Biological Research—Branch of NIRDBS, 47 Lascar Catargi Street, 700107 Iasi, Romania; \\ cosmin-teodor.mihai@umfiasi.ro (C.-T.M.); gabrielacapraru@yahoo.com (G.V.) \\ 4 Advanced Center for Research and Development in Experimental Medicine (CEMEX), Gr.T.Popa Medicine \\ and Pharmacy University of Iasi, 9-13. M. Kogalniceanu, 700115 Iasi, Romania \\ * Correspondence: mariusgrigorepsyche@yahoo.com (M.-N.G.); daniela_gherghel@yahoo.com (D.G.)
}

Received: 12 August 2020; Accepted: 17 September 2020; Published: 18 September 2020

\begin{abstract}
The present paper examines the effects of salt stress on the growth, pigments, lipid peroxidation and antioxidant ability of barley (Hordeum vulgare L.) seedlings raised from proton beam irradiated caryopses. In order to assess the effects of radiation on the early stages of plant growth and analyze its possible influence on the alleviation of salinity, 3 and 5 Gy doses were used on dried barley seeds and germination occurred in the presence/absence of $\mathrm{NaCl}(100 \mathrm{mM}$ and $200 \mathrm{mM}$ ). After treatment, photosynthetic pigments increased in the 5 Gy variant, which registered a higher value than the control. Among the antioxidant enzymes studied (SOD, CAT, and POD) only CAT activity increased in proton beam irradiated seeds germinated under salinity conditions, which indicates the activation of antioxidant defense. The malondialdehyde (MDA) content declined with the increase of irradiation doses on seeds germinated at $200 \mathrm{mM} \mathrm{NaCl}$. On the other hand, the concentration of $200 \mathrm{mM} \mathrm{NaCl}$ applied alone or combined with radiation revealed an increase in soluble protein content. The growth rate suggests that $3 \mathrm{~Gy}$ proton beam irradiation of barley seeds can alleviate the harmful effects of $100 \mathrm{mM} \mathrm{NaCl}$ salinity, given that seedlings' growth rate increased by $1.95 \%$ compared to the control.
\end{abstract}

Keywords: beam proton radiation; saline stress; antioxidant protection systems; barley

\section{Introduction}

Barley (Hordeum vulgare L.), which belongs to the Poaceae family, is the fourth most important cereal crop in the world after wheat, corn, and rice and is almost in the top ten crop plants in the world. Barley is used to produce starch, either for food or for the chemical industry. Although in the past barley was mainly consumed by people, today it is usually used to feed livestock and to produce malt, and only in small quantities for direct human consumption. In addition, barley has medicinal applications in many diseases, such as anti-cough, bladder inflammation, blood sugar levels, cholera, dermatitis, diabetes [1,2].

Barley is a salt-tolerant species that presents a greater degree of salt tolerance compared to rice (Oryza sativa) and wheat (Triticum aestivum). Barley is most sensitive to salinity at the time of germination and in the early seedlings stage, but it becomes more tolerant as it grows. Saline sensitivity 
in the seedling stage has been attributed mainly to the ionic effects and lesser to the osmotic action $[3,4]$. Some studies revealed a wide interspecific variability for salt tolerance in cereals during germination, and the response to salt depends on the species, the variety, the salt concentration of the field, and the plant development stage [5]. Generally, salinity is known to be one of the most common environmental stresses affecting physiological and biochemical processes.

In order to alleviate salinity stress, seeds, seedlings, or plants are exposed to several chemical, biological, and physical treatments. In this way, a series of molecular and physiological mechanisms are activated, which enables the seed or the plant to respond faster and/or stronger after exposure to salinity [6].

Various strategies have been used to improve crop growth in saline conditions, including the production of salt-tolerant genotypes. These may include the use of the plant growth regulators-PGR $[7,8]$, the phytohormones [9,10], or plant growth-promoting rhizobacteria-PGPR [11,12] in order to diminish or eliminate the negative effects of salinity and to obtain the plants that are able to manage salinity stress. In addition, numerous studies of gamma radiation and salinity effects, applied separately or simultaneously, on mono- or dicotyledonous species, such as: Oryza sativa [13,14], Medicago sativa [15], Ambrosia maritime [16], Vigna sinensis [17], Osmanthus fragrans [18], Moringa oleifera [19], have been performed. According to Macovei et al. [13], gamma irradiation treatment can enhance the resistance of some plants to abiotic stress conditions, such as salt and drought, by intensification of antioxidant enzymes activity and activation of Transcription-Coupled Nucleotide Excision Repair (TC-NER) pathway. However, there is little data on the influence of proton beam irradiation on plant salinity tolerance and even less on that of barley.

Some studies mention that the biological effects of radiation on plants are strongly influenced by a variety of factors related to (i) plant particularities such as: the species and cultivar, the growth stage, the tissue architecture, and hereditary material, and (ii) radiation characteristics, such as intensity, quality, dose-rate, and the duration of exposure [20].

Mutation breeding is an alternative method used to improve agronomic traits, such as stress resistance, physical parameters of grain, and nutritional value. It is known that ionizing radiation helps overcome the limitations of the chemical treatment so that new mutations can be generated in a short period [21-23]. There are two forms of ionizing radiation that transfer energy into a substance: non-particulate (gamma and $\mathrm{X}$ rays) and particulate (alpha and beta particles, neutrons, and protons). Recent studies revealed that, in barley, ion beams including protons have an important role in mutation breeding, given that positively charged ions are accelerated at a high speed (approximately $20-80 \%$ of the speed of light) and constitute the high linear transfer radiation (LET) used for irradiation of target cells [24]. In contrast to low linear energy transfer radiation (e.g., gamma and X-rays), which represents the application of a high amount of energy to a small area, the ion beam provides high LET when aligned along the direction of the beam. The biological effects on plants are bigger in case of higher LET radiation than low LET radiation. Taking into account the structure of the cereal grain, the ion beam can easily penetrate the coat of the caryopses and reach the meristematic tissue of the embryo with a high irradiation efficiency [25].

Some studies [26,27] focus on the use of proton irradiation used to induce genetic variability in crop plants in order to create new varieties with production performance and high tolerance to various stressors (salinity, herbicides, etc.), which are beneficial to farmers.

The biological response to radiations mainly depends on the type of radiation, type of interaction, and also the way energy is deposited in tissues $[28,29]$.

In this paper we dealt with irradiation and salt treatments as abiotic stress factors; therefore, we intended to test the effects of a multiple stress on seedlings of Hordeum vulgare. While salt stress solely has a long history in plant physiology and biochemistry, combining it with other types of stress is rather a novel approach; within these other factors, proton beam irradiation has been rarely reported to be used as an additional stressful factor on plants. On the other hand, proton beam has emerged as a novel mutagen in mutation breeding of crop plants. Mutation breeding using ionizing radiation has 
been used as a useful tool for creating genetic variability and crop improvement. Despite our paper is not focused on mutations in investigated species, it is useful, however, to test some biochemical indices in Hordeum sp. under salt stress conditions and irradiation treatment in order to achieve a good picture of plant responses. It has been reported that proton beam can be used in creating novel variability that will be beneficial to the farmers; as Hordeum sp. is an important crop, with a certain degree of salt tolerance, it would be beneficial to have some answers regarding the biochemical adaptive profile of this species under a scenario of aridization, salinization, and climate change.

In this context, the present study was designed to explore the physiological and biochemical responses of Hordeum vulgare seedling to salt stress (100 and $200 \mathrm{mM} \mathrm{NaCl})$ and to determine how proton beam irradiation pretreatment of seeds ( 3 and 5 Gy) improves barley tolerance by modulating antioxidant activity and reactive oxygen species (ROS) balance.

\section{Materials and Methods}

\subsection{Experimental Design of Plant Material and Growing Conditions}

Barley (Hordeum vulgare ssp. vulgare) seeds were kindly provided by the Agricultural Research and Development Station, Secuieni Neamt, Romania. The study of barley seedling tolerance to salinity and proton beam irradiation pretreatment was conducted under laboratory conditions, based on completely randomized design with three replications.

\subsubsection{Proton Beam Irradiation}

The monolayer of dry barley caryopses was placed in Petri dishes and exposed to a proton beam accelerated to $150 \mathrm{MeV}$ with a dose of 0,3, and $5 \mathrm{~Gy}$ at room temperature. Irradiation was performed at the protons linear accelerator facility in the phasotron Dzhelepov Laboratory of Nuclear Problems from JINR (Dubna). The beam energy in the cabin was determined by the range of the beam in water $(\mathrm{R}=200 \mathrm{~mm}$ of water), and the average LET, $\mathrm{dE} / \mathrm{dx}=0.539 \mathrm{keV} / \mu \mathrm{m}$, where $\mathrm{dE}$ represents energy loss and $\mathrm{dx}$ is the increment of path length.

\subsubsection{Growth Conditions and Salinity Treatment}

The grains used in the study were healthy, smooth, and intact and were of similar size and color. For each variant, twenty-five seeds were disinfected with 5\% sodium hypochlorite for $15 \mathrm{~min}$ and then thoroughly washed with sterile distilled water. For germination, the caryopses were placed in Petri dishes at $25^{\circ} \mathrm{C}$ in the dark for $72 \mathrm{~h}$ and then were transferred into a growth chamber at $23^{\circ} \mathrm{C}$ under photoperiod conditions-16/8 h (light/dark). Afterward, treatments started by daily addition of $2 \mathrm{~mL}$ of salt solutions (or distilled water for the control and single irradiated seeds). Saline stress was replicated by two concentrations of $\mathrm{NaCl}(100 \mathrm{mM}, 200 \mathrm{mM})$. This study consisted of eight treatments with saline and proton irradiation applied on barley caryopses (alone or combined) as follows: $3 \mathrm{~Gy}$, $5 \mathrm{~Gy}, 100 \mathrm{mM} \mathrm{NaCl}, 200 \mathrm{mM} \mathrm{NaCl}, 3 \mathrm{~Gy}+100 \mathrm{mM} \mathrm{NaCl}, 3 \mathrm{~Gy}+200 \mathrm{mM} \mathrm{NaCl}, 5 \mathrm{~Gy}+100 \mathrm{mM}$ $\mathrm{NaCl}, 5 \mathrm{~Gy}+200 \mathrm{mM} \mathrm{NaCl}$. The variant without application of treatments (0 Gy and $0 \mathrm{mM} \mathrm{NaCl})$ was used as control. Physiological and biochemical analyses were conducted at 16-days-old seedlings; five different individuals from each treatment were selected to measure all the analyzed parameters.

\subsection{Photosynthetic Pigments Analysis}

The photosynthetic pigments viz. chlorophyll $a$, chlorophyll $b$, and carotenoids from 16 -days-old barley seedlings (10 mg) were extracted with $80 \%$ acetone and quantified following Reference [30]. Optical density of supernatant was measured with UV-visible spectrophotometer at $663 \mathrm{~nm}$ (chlorophyll $a$ ), $646 \mathrm{~nm}$ (chlorophyll $b$ ), and $470 \mathrm{~nm}$ (xanthophyll and carotenoids). The amount of 
pigments was evaluated and expressed in $\mathrm{mg} \mathrm{g}^{-1}$ fresh weight (FW) using the following equations, in agreement as stated by Lichtenthaler [30]:

$$
\begin{gathered}
\text { Chlorophyll } a(\mathrm{Chl} a)=(12.21 \times \mathrm{A} 663-2.81 \times \mathrm{A} 645) \\
\text { Chlorophyll } b(\mathrm{Chl} b)=(20.13 \times \mathrm{A} 645-5.03 \times \mathrm{A} 663) \\
\text { Carotenoids }=[(1000 \times \mathrm{A} 470-3.27 \times \mathrm{Chl} \mathrm{a}-104 \times \mathrm{Chl} \mathrm{b}) / 227]
\end{gathered}
$$

\subsection{Oxidative Stress Indexes}

Malondialdehyde (MDA) as an indicator of lipid peroxidation products was quantified in fresh barley leaves according to the method described in Reference [31]. Thus, $0.20 \mathrm{~g}$ of samples were collected and homogenized thoroughly in 10\% trichloracetic acid (TCA), followed by centrifugation for $10 \mathrm{~min}$ at $400 \mathrm{rpm} / \mathrm{min}$. One milliliter from the supernatant sample was mixed with $2 \mathrm{~mL}$ of $0.5 \%$ thiobarbituric acid (TBA) solution (in $10 \%$ TCA). The mixture was kept at $95^{\circ} \mathrm{C}$ for 60 min and cooled at room temperature, then centrifuged at 12,000 rpm for $10 \mathrm{~min}$ to remove the interfering substances. Absorbance was recorded at $532 \mathrm{~nm}$ using UV-VIS spectrophotometer (Model Pharma Spec UV-1700 Shimadzu, Kioto, Japan).

\subsection{Antioxidant Defense System}

\subsubsection{Non-Enzymatic Constituents}

Total Polyphenols Content

The total content of polyphenols was established using the modified Folin-Ciocalteu method [32]. The absorbance of the blue-colored solution obtained was evaluated at $765 \mathrm{~nm}$ after two hours, using the distilled water as a blank. The quantity of the total polyphenolic content was expressed as milligram equivalents of gallic acid/gram of dry weight $\left(m g\right.$ GAE g $\left.{ }^{-1} \mathrm{DW}\right)\left(\mathrm{R}^{2}=0.99\right)$. For each sample, three measurements were taken and the averages were calculated.

Flavonoids Content

The content of flavonoids was assessed by spectrophotometric method [33]. The absorbance of the pink-colored solution obtained after reactions was estimated at $510 \mathrm{~nm}$ compared to the blank (distilled water). Flavonoids amount was expressed as mg catechin equivalent (mg CE g $\left.{ }^{-1} \mathrm{DW}\right)\left(\mathrm{R}^{2}=0.98\right)$. The average of the three repetitions for each sample was established.

\subsubsection{Antioxidant Enzymes}

Preparation of Enzyme Extracts

In order to obtain the crude enzyme extract, $0.30 \mathrm{~g}$ of fresh 16-days-old seedlings of each sample was homogenized with $3 \mathrm{~mL} 0.1 \mathrm{M}$ sodium phosphate buffer solution $(\mathrm{pH}=7.5)$. Homogenates were centrifuged at $15,000 \mathrm{rpm} / \mathrm{min}$ at $4{ }^{\circ} \mathrm{C}$ for $15 \mathrm{~min}$. Supernatants containing crude enzymes were analyzed for activities of superoxide dismutase SOD, CAT, and POD.

\section{SOD Activity}

SOD activity was evaluated by monitoring its ability to inhibit the reduction of nitro blue tetrazolium (NBT) by the superoxide radicals resulted via reoxidation of photochemically reduced riboflavin [34]. The reaction mixture included $1.5 \mathrm{~mL}$ phosphate buffer $(50 \mathrm{mM}, \mathrm{pH} 7.8), 0.5 \mathrm{~mL} 0.1 \mathrm{mM}$ EDTA, $0.5 \mathrm{~mL} 130 \mathrm{mM}$ methionine, $0.5 \mathrm{~mL} 0.5 \mathrm{mM} \mathrm{NBT}$, $0.5 \mathrm{~mL} 0.02 \mathrm{mM}$ riboflavin, and $0.05 \mathrm{~mL}$ enzyme extract with a final volume of $3 \mathrm{~mL}$. Riboflavin was added last, and the samples were illuminated by placing the tubes below a light source of $215 \mathrm{~W}$ fluorescent lamps for exactly $5 \mathrm{~min}$. One unit of SOD 
activity is described as the quantity of enzyme necessary to determine $50 \%$ inhibition of the reduction of NBT recorded at $560 \mathrm{~nm}$.

\section{POD Activity}

POD activity was spectrophotometrically established by measuring the color intensity generated by the oxidation of o-dianisidine (3,30-dimethoxybenzidine) with $\mathrm{H}_{2} \mathrm{O}_{2}$ in the presence of peroxidase at $460 \mathrm{~nm}$, using the method described by Ranieri et al. [35]. Initiation of the reaction was assured by addition of $50 \mu \mathrm{L}$ extract to the reaction mixture represented by $20 \mathrm{mM}$ phosphate buffer ( $\mathrm{pH} 5.0$ ), $1 \mathrm{mM}$ o-dianisidine, and $3 \mathrm{mM} \mathrm{H}_{2} \mathrm{O}_{2}$. Specific activity of POD was expressed as the amount of enzyme that produced a change of 1.0 absorbance per min, expressed as units ( $\mathrm{mM}$ of oxidized dianisidine per min) per mg protein.

\section{CAT Activity}

CAT activity was determined by Sinha's assay with minor adjustments [36]. The reaction mixture consisted of $0.4 \mathrm{~mL}$ phosphate buffer $(0.01 \mathrm{M}, \mathrm{pH} 7.0), 0.5 \mathrm{~mL}$ hydrogen peroxide $(0.16 \mathrm{M})$, and $0.1 \mathrm{~mL}$ enzyme extract reaching a final volume of $3.0 \mathrm{~mL}$. About $2 \mathrm{~mL}$ dichromate acetic acid reagent was added in $1 \mathrm{~mL}$ of reaction mixture, boiled for $10 \mathrm{~min}$, and then cooled. After stopping the catalase action, the amount of unmodified hydrogen peroxide, which reduces potassium dichromate to chromium acetate in an acid medium, was recorded at $570 \mathrm{~nm}$. Therefore, CAT activity is reported as the amount of enzyme needed to reduce $1 \mu \mathrm{mol}$ of $\mathrm{H}_{2} \mathrm{O}_{2}$ per min.

The activity of all antioxidant enzymes (SOD, POD, and CAT) was expressed as unit per mg proteins ( $\mathrm{U} \mathrm{mg}^{-1}$ protein).

The soluble protein content was assessed by Bradford's method (1976) [37] using bovine serum albumin as standard. This method consists of the binding of Coomassie Brilliant Blue G-250 to the aromatic amino acid radicals and the measurement of extinction at $595 \mathrm{~nm}$. The results are expressed in $\mathrm{mg}$ protein per $\mathrm{g}$ fresh weight (FW).

To compare the sensitivity of each parameter, the increase/decrease rates were established by the following equation: $(1-x / y) \times 100$, where $y$ is the average value detected in the control and $x$ is one of each treated sample.

Statistical analysis. All experiments were performed using three independent repetitions and the results were expressed as the mean values \pm standard errors (SE). The statistical significance of the differences between treated samples and control ones was assessed by means of the Student's $t$ test. The differences were considered as significant at levels of $p<0.05$ and were represented by statistical lettering. The increase/decrease $(-/+)$ rates were calculated based on the equation: $(1-x / y) \times 100$, where $y$ is the average value detected in the control and $x$ is one of each treated samples.

\section{Results and Discussions}

\subsection{Tolerance of Proton Beam Irradiated Barley Seedlings to Salinity Stress}

The length of seedlings elongation showed declining tendency with each increasing doses of proton beam radiation as well as salinity concentrations after single treatment application. The results showed that the lowest beam irradiation dose (3 Gy) resulted in a 1.38\% decrease in the length of barley seedlings, while in the case of the 5 Gy dose the decrease was 5.10\% (Table 1 and Figure 1). In addition, the application of a $100 \mathrm{mM}$ salinity concentrate resulted in a slight increase $(5.93 \%)$ of seedlings length and a significant decrease (58.62\%) in the growth rate at the maximum concentration of $\mathrm{NaCl}(200 \mathrm{mM})$. In the case of irradiation pretreatment, after $100 \mathrm{mM} \mathrm{NaCl}$ application, the seedlings length at $3 \mathrm{~Gy}$ increased by $1.93 \%$ and decreased by $4.21 \%$ after $5 \mathrm{~Gy}$ proton beam irradiation. On the other hand, the results of germination in presence of $200 \mathrm{mM} \mathrm{NaCl}$ indicated a significant decrease of barley growth by $72.90 \%(p<0.001)$ and $73.93 \%(p<0.001)$ respectively, at $3 \mathrm{~Gy}$ and 5 Gy proton beam 
irradiation, respectively. This shows that $3 \mathrm{~Gy}$ proton beam irradiation can alleviate the harmful effect of $100 \mathrm{mM} \mathrm{NaCl}$ salinity, as demonstrated by the significant growth rates of barley seedlings.

Generally, low doses of irradiation stimulate germination and seedlings growth, while high doses inhibit seeds growth, while the sensitivity of each applied dose varies depending on the type of radiation and the tested species. For example, Wi et al. [38] obtained a slight stimulation of the growth of Arabidopsis seedlings when the seeds were exposed to 1 or 2 Gy, while a 50 Gy dose had an inhibitory effect. Singh and Datta [39] showed that 10-100 Gy doses improved the germination potential of wheat seeds. In addition, gamma radiations represent one of the most powerful agents that can alter the physiological and biochemical properties of plants in correlation with the absorbed doses, and higher doses have an inhibitory effect on plants by generation of free radicals with repercussions on physiological, morphological, and anatomical processes depending on the level of irradiation $[40,41]$. The dry and water-imbibed Arabidopsis seeds irradiated with $2.6 \mathrm{MeV} \mathrm{H}^{+}$and $6.5 \mathrm{MeV} \mathrm{H}^{+}$have shown a rapid reduction of germination and survival rate, with water-soaked seeds having a higher sensitivity to irradiation compared to dry ones [42]. Furthermore, the proton beam pretreatment of rice seeds $(0,50,100,200,300,400,500,600,700$, and $800 \mathrm{~Gy})$ induced a significant reduction in the rate of germination (over 30\%) at doses higher than $300 \mathrm{~Gy}$, and an increase in the height roots and shoots at 50 and 100 Gy, 14 days after irradiation [43]. Recent studies [44] have revealed a linear decrease in germination rate after the application of increasing doses of the proton beam, ranging from 0-500 Gy, upon Indian rice variety (Oryza sativa L.). Similar results were obtained by Bae et al. [45] indicating a decrease in the germination rate of tobacco and rice seeds as the dose proton beam and the irradiation time increased, which suggests that this type of irradiation can be used as a mutagenic agent for obtaining new useful varieties. For example, Gonzalez et al. [46] state that they obtained the first rice cultivar with improved productive potential and tolerance to salinity by proton irradiation of rice seeds belonging to variety J-104. Moreover, Im et al. [47] using 57-MeV proton beam treatment (50-400 Gy) obtained an increase of germination rate but a strong reduction of survival rates in soybean plants. They mentioned that optimal doses for breeding mutation are between 250 and $300 \mathrm{~Gy}$. Regarding the salinity stress effects, growth inhibition is a common response to $\mathrm{NaCl}$ and depends on tolerance of the plants/seedling as well as the salt concentration [48].

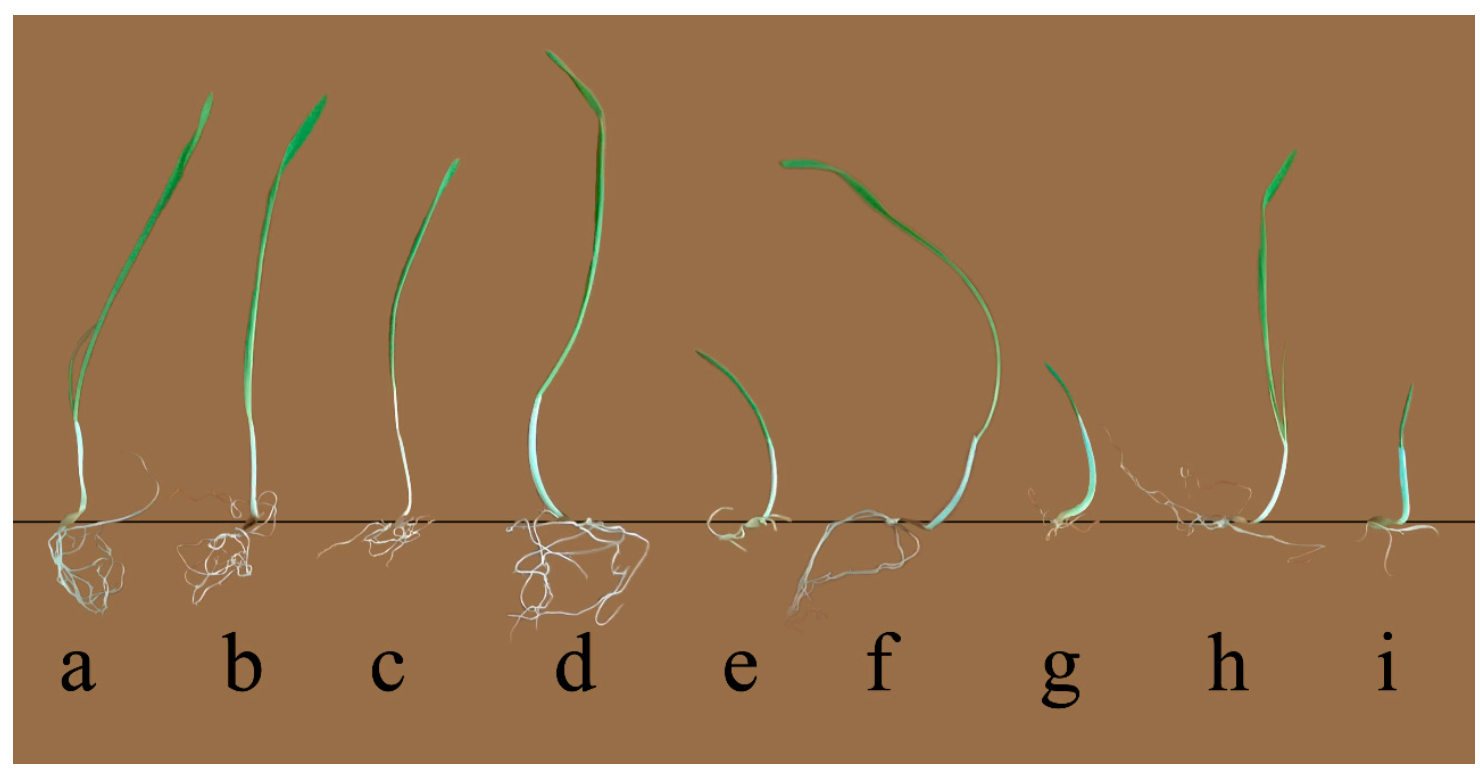

Figure 1. The phenotypic appearance of non-irradiated (0 Gy) and irradiated (3 Gy and 5 Gy) barley seedling grown with (100 and $200 \mathrm{NaCl}$ ) and without salinity: (a) Control, (b) $3 \mathrm{~Gy}$, (c) $5 \mathrm{~Gy}$, (d) $100 \mathrm{mM}$ $\mathrm{NaCl}$, (e) $200 \mathrm{mM} \mathrm{NaCl}$, (f) $3 \mathrm{~Gy}+100 \mathrm{mM} \mathrm{NaCl}$, (g) $3 \mathrm{~Gy}+200 \mathrm{mM} \mathrm{NaCl}$, (h) $5 \mathrm{~Gy}+100 \mathrm{mM} \mathrm{NaCl}$, (i) $5 \mathrm{~Gy}+200 \mathrm{mM} \mathrm{NaCl}$. 
Table 1. The effect of proton beam irradiation on 16-days-old Hordeum vulgare seedlings length in presence of salt stress. Means values $( \pm \mathrm{SE})$ of 10 replicates.

\begin{tabular}{ccccc}
\hline Samples & Means Values $\mathbf{( c m )}$ & $\mathbf{P}<$ & $\mathbf{\%}$ & $-/+$ Rate (\%) \\
\hline Control & $14.50 \pm 0.90$ & & & \\
$3 \mathrm{~Gy}$ & $14.30 \pm 0.78$ & $\mathrm{NS}$ & 98.62 & -1.38 \\
$5 \mathrm{~Gy}$ & $13.76 \pm 0.78$ & $\mathrm{NS}$ & 94.90 & -5.10 \\
$100 \mathrm{mM} \mathrm{NaCl}$ & $15.36 \pm 0.99$ & $\mathrm{NS}$ & 105.93 & 5.93 \\
$200 \mathrm{mM} \mathrm{NaCl}$ & $6.00 \pm 0.35$ & $p<0.001$ & 41.38 & -58.62 \\
$3 \mathrm{~Gy}+100 \mathrm{mM} \mathrm{NaCl}$ & $14.78 \pm 0.49$ & $\mathrm{NS}$ & 101.93 & 1.93 \\
$3 \mathrm{~Gy}+200 \mathrm{mM} \mathrm{NaCl}$ & $3.93 \pm 0.27$ & $p<0.001$ & 27.10 & -72.90 \\
$5 \mathrm{~Gy}+100 \mathrm{mM} \mathrm{NaCl}$ & $13.89 \pm 0.59$ & $\mathrm{NS}$ & 95.79 & -4.21 \\
$5 \mathrm{~Gy}+200 \mathrm{mM} \mathrm{NaCl}$ & $3.78 \pm 0.33$ & $p<0.001$ & 26.07 & -73.93 \\
\hline
\end{tabular}

\subsection{Effect of Salinity and Proton Irradiation on Photosynthetic Pigments Content of Barley Seedlings}

Photosynthetic pigments such as chlorophyll a $(\mathrm{Chl} a)$, chlorophyll $b(\mathrm{Chl} b)$, and carotenoids were affected in the sense of decreasing them by the applied treatments (Table 2). Regarding the content of $\mathrm{Chl} a$, it was observed that was higher than the control, only at 5 Gy. Under salt stress (100 $\mathrm{mM}$ and $200 \mathrm{mM} \mathrm{NaCl}$ ), the pigments content in barley seedlings diminished as salinity increased. Our results are similar to Baek et al. [49], which showed lower chlorophylls content and a decrease in the effective quantum yield of photosystem 2 in the $\mathrm{NaCl}$-treated rice seedlings.

Table 2. Modulation of the photosynthetic pigments content in 16-days-old seedlings Hordeum vulgare as response to salt stress and proton beam irradiation.

\begin{tabular}{|c|c|c|c|}
\hline Sample & $\begin{array}{l}\text { Chlorophyll } a \\
\left(\mathrm{mg} \mathrm{g}^{-1} \text { FW) }\right.\end{array}$ & $\begin{array}{l}\text { Chlorophyll b } \\
\left(\mathrm{mg} \mathrm{g}^{-1} \text { FW) }\right.\end{array}$ & $\begin{array}{l}\text { Carotenoids } \\
\left(\mathrm{mg} \mathrm{g}^{-1} \mathrm{FW}\right)\end{array}$ \\
\hline Control & $0.622 \pm 0.026^{a}$ & $0.160 \pm 0.008^{a}$ & $0.143 \pm 0.005^{\mathrm{a}}$ \\
\hline 3 Gy & $0.482 \pm 0.064$ & $0.129 \pm 0.018$ & $0.095 \pm 0.017$ \\
\hline 5 Gy & $0.649 \pm 0.132$ & $0.165 \pm 0.029$ & $0.130 \pm 0.043$ \\
\hline $100 \mathrm{mM} \mathrm{NaCl}$ & $0.433 \pm 0.079$ & $0.126 \pm 0.015$ & $0.111 \pm 0.019$ \\
\hline $200 \mathrm{mM} \mathrm{NaCl}$ & $0.345 \pm 0.039^{b}$ & $0.101 \pm 0.008^{b}$ & $0.074 \pm 0.009^{b}$ \\
\hline $3 \mathrm{~Gy}+100 \mathrm{mM} \mathrm{NaCl}$ & $0.267 \pm 0.013^{b}$ & $0.072 \pm 0.015^{b}$ & $0.061 \pm 0.013$ \\
\hline $3 \mathrm{~Gy}+200 \mathrm{mM} \mathrm{NaCl}$ & $0.371 \pm 0.002^{b}$ & $0.103 \pm 0.012$ & $0.074 \pm 0.006^{b}$ \\
\hline $5 \mathrm{~Gy}+100 \mathrm{mM} \mathrm{NaCl}$ & $0.434 \pm 0.092$ & $0.239 \pm 0.028$ & $0.117 \pm 0.014$ \\
\hline $5 \mathrm{~Gy}+200 \mathrm{mM} \mathrm{NaCl}$ & $0.570 \pm 0.045$ & $0.173 \pm 0.008$ & $0.108 \pm 0.009$ \\
\hline
\end{tabular}

Values are mean of three experiments $\pm \mathrm{SE}$; letters are designating the significant difference between samples and control group.

The seeds irradiated with $3 \mathrm{~Gy}$, grown in $100 \mathrm{mM}$ and $200 \mathrm{mM} \mathrm{NaCl}$ salinity conditions, revealed a significant decrease in $\mathrm{Chl} a(p<0.01)$. In addition, a significant decrease was observed in case of Chl $b$ at $200 \mathrm{mM} \mathrm{NaCl}$ and $3 \mathrm{~Gy}+100 \mathrm{mM} \mathrm{NaCl}(p<0.05)$ while at carotenoids at $3 \mathrm{~Gy}+200 \mathrm{mM} \mathrm{NaCl}$ $(p<0.01)$.

The highest decrease in $\mathrm{Chl} a$ content in barley seedlings, as a response to all types of stress, simple or combined, was at $3 \mathrm{~Gy}+100 \mathrm{mM} \mathrm{NaCl}$ variant, which was 2.33 times lower compared to the control. A similar pattern to the Chl $a$ was observed in the content of $\mathrm{Chl} b$ and carotenoids in all analyzed samples. Malanga et al. [50] stated that the decrease of the total Chl content could be the consequence of the alteration of the photosynthetic capacity of chloroplasts. Our results are in accordance with those reported by References [51,52] in which total Chl contents decreased with the increase of $\mathrm{NaCl}$ concentrations. Several studies have shown that low doses of gamma rays applied on seeds stimulate germination, plant growth, and synthesis of photosynthetic pigments [53]. However, Macovei et al. [13] showed that single gamma irradiation of seeds (25 to $200 \mathrm{~Gy}$ ) induced significant decrease in chlorophyll content in 20-day-old rice plantlets, which contained a higher level of Chl $b$. On the other hand, the low dose rate irradiated seeds $(25 \mathrm{~Gy}$ ) grown in the presence of $100 \mathrm{mM} \mathrm{NaCl}$ 
revealed a significant increase in $\mathrm{Chl} a$ and $b$, and a slight difference was recorded after high dose rate (100 and 200 Gy) treatments.

Decrease of chlorophyll content is an important indicator of the senescence foliar process and further a significant marker of physiological reactions in response to xenobiotic stress [54]. Kalimullah et al. [55] mentioned that ${ }^{1} \mathrm{H}$ heavy ion radiation can inhibit chlorophyll biosynthesis and, similarly, gamma rays and proton beam irradiation alter photosynthetic pigments, leading to alteration of the photosynthesis process [56].

Compare to the pigments $\mathrm{Chl} a$ and $\mathrm{Chl} b$, the carotenoid content showed the same decreasing tendency, compared to the control, when applying simple and combined treatments of stress and radiation. Carotenoid pigments, component of the plant photosynthetic apparatus and non-enzymatic antioxidants that maintain homeostasis in the plant, can protect cell membranes from the effect of oxidative stress caused by many agents, including salinity or radiations. The carotenoids content in 3 Gy and 5 Gy samples decreased by $33.50 \%$ and $9.10 \%$, respectively, compared to the control. The 100 to $200 \mathrm{mM} \mathrm{NaCl}$ treatments induced a reduction of the carotenoids level in the barley seedlings by $22.64 \%$ and $48.22 \%$, respectively. Consistent with our results, Reference [57] reported that salinity causes a decrease in the content of carotenoid pigments with a negative effect on the process of photosynthesis and the mechanisms of defense against oxidative stress.

\subsection{Effects of Proton Irradiation on ROS Scavenging Systems of Barley Seedling in Response to Salt Stress}

In order to determine the antioxidant responses of barley irradiated seeds ( 3 and $5 \mathrm{~Gy}$ ) germinated under saline stress conditions (100 $\mathrm{mM}$ and $200 \mathrm{mM} \mathrm{NaCl})$, the enzymatic activity of SOD, POD, and CAT in 16-days-old barley seedlings were measured.

SOD activity, which is the first line of cell defense against ROS generated by saline and radiation treatments, had higher values only at $3 \mathrm{~Gy}$ and $5 \mathrm{~Gy}$ irradiated seedlings compared to the control, with an increase of only $6.24 \%$ and $2.43 \%$, respectively. Meanwhile, when barley seedling germinated on $100 \mathrm{mM}$ and $200 \mathrm{mM} \mathrm{NaCl}$, the activity of SOD had relatively close values, being lower compared to the control $(8.48 \%$ and $7.45 \%$ ) (Figure 2$)$. There was no major difference in response to SOD activity in 16-days-old barley seedlings irradiated with 3 and 5 Gy and grown under saline stress conditions (200 $\mathrm{mM}$ and $100 \mathrm{mM} \mathrm{NaCl}$ ).

Out of the three antioxidant enzymes studied, CAT showed the highest enzymatic activity in response to alone actions of protons compared with the control (Figure 3). Single proton 3 Gy beam irradiation determined an increase in CAT activity by $11.61 \%$, while in the case of 5 Gy irradiation the increase was $132 \%$. On the other hand, there were no major differences in the CAT response to the two concentrations of $\mathrm{NaCl}(100 \mathrm{mM}$ and $200 \mathrm{mM} \mathrm{NaCl})$ applied alone but the increase was by $113.41 \%$ and $110.99 \%$ when compared to the control. In barley seeds irradiated with $3 \mathrm{~Gy}$, which have germinated on $100 \mathrm{mM}$ and $200 \mathrm{mM} \mathrm{NaCl}$, CAT activity increased by $104 \%$ and $40 \%$, respectively, compared to the control. In contrast, CAT activity showed a $40.12 \%$ and $38.62 \%$ increase compared to the control in 5 Gy-irradiated barley seeds and germinated on $100 \mathrm{mM}$ and $200 \mathrm{mM} \mathrm{NaCl}$. 


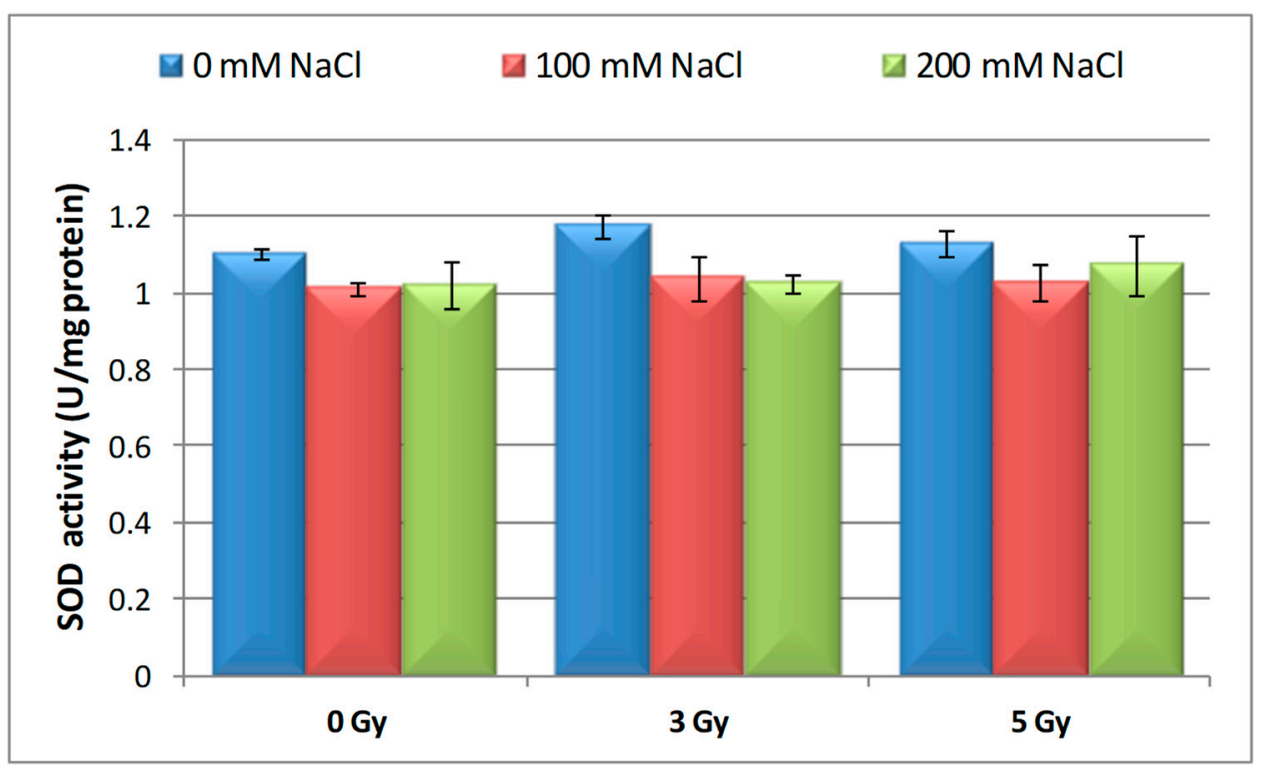

Figure 2. Effect of proton beam irradiation doses on the superoxide dismutase (SOD) activity in 16-days-old seedlings Hordeum vulgare as response to salt stress.

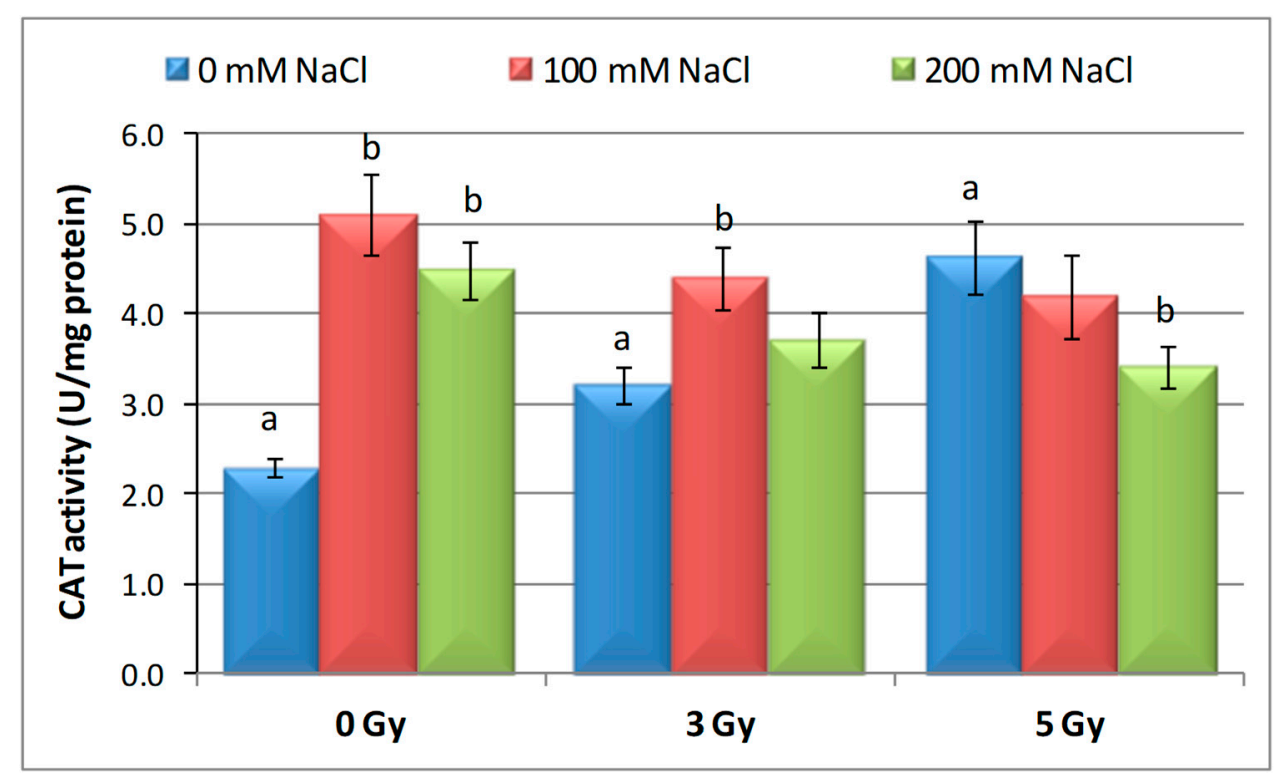

Figure 3. Effect of proton beam irradiation doses on the CAT activity in 16-days-old seedlings Hordeum vulgare as response to salt stress. Values are mean of three experiments $\pm \mathrm{SE}$; letters are designating the significant difference between samples and control group.

When compared to the control, there was little increase in POD activity $(7.38 \%, 2.75 \%$, and $2.24 \%)$ after barley seeds irradiation with the two doses ( 3 and 5 Gy), as well as after 3 Gy irradiation of seedlings germinated on $100 \mathrm{mM} \mathrm{NaCl}$ (Figure 4, Table 3). It is interesting to note the fact that under saline conditions a decrease in POD activity $(19.38 \%$ and $3.48 \%)$ was observed in barley seedlings germinated on $100 \mathrm{mM}$ and $200 \mathrm{mM} \mathrm{NaCl}$ compared to the control. POD activity was influenced more intensely when 3 and 5 Gy irradiated barley seeds germinated in the presence of $200 \mathrm{mM}$ than of $100 \mathrm{mM} \mathrm{NaCl}$ if we refer to the seeds irradiated only with the appropriate doses. Effect of proton beam radiation doses on antioxidant enzymes (SOD, CAT, and POD) activity investigated in this study on 16-days-old barley seedlings in response to the salt stress was heterogeneous. 
Table 3. Modulation of the main biochemical indicators after proton beam irradiation in 16-days-old seedlings Hordeum vulgare as response to salt stress.

\begin{tabular}{|c|c|c|c|c|c|c|c|c|c|c|c|c|c|c|}
\hline Samples & $\begin{array}{c}\text { SOD } \\
\text { Activity }\end{array}$ & $\begin{array}{c}-/+ \\
\text { Rate } \\
(\%)\end{array}$ & $\begin{array}{c}\text { CAT } \\
\text { Activity }\end{array}$ & $\begin{array}{c}-/+ \\
\text { Rate } \\
(\%)\end{array}$ & $\begin{array}{c}\text { POD } \\
\text { Activity }\end{array}$ & $\begin{array}{c}-/+ \\
\text { Rate } \\
(\%)\end{array}$ & $\begin{array}{c}\text { MDA } \\
\text { Content }\end{array}$ & $\begin{array}{c}-/+ \\
\text { Rate } \\
(\%)\end{array}$ & $\begin{array}{c}\text { Flavonoid } \\
\text { Content }\end{array}$ & $\begin{array}{c}-/+ \\
\text { Rate } \\
(\%)\end{array}$ & $\begin{array}{c}\text { Polyphenol } \\
\text { Content }\end{array}$ & $\begin{array}{l}-/+ \\
\text { Rate } \\
(\%)\end{array}$ & $\begin{array}{l}\text { Soluble } \\
\text { Protein } \\
\text { Content }\end{array}$ & $\begin{array}{l}-/+ \\
\text { Rate } \\
(\%)\end{array}$ \\
\hline Control & 1.10 & 0.00 & $2.30^{\mathrm{a}}$ & 0.00 & 0.40 & 0.00 & 12.11 & 0.00 & $12.09^{\mathrm{a}}$ & 0.00 & 16.67 & 0.00 & 29.34 & 0.00 \\
\hline $3 \mathrm{~Gy}$ & 1.17 & 6.36 & 2.56 & 11.30 & 0.43 & 7.50 & 10.60 & -12.47 & 20.11 & 66.34 & 13.52 & -18.90 & 27.41 & -6.58 \\
\hline $5 \mathrm{~Gy}$ & 1.13 & 2.73 & 5.35 & 132.61 & 0.41 & 2.50 & 10.85 & -10.40 & 13.32 & 10.17 & 6.82 & -59.09 & $30.22^{\mathrm{a}}$ & 3.00 \\
\hline $100 \mathrm{mM} \mathrm{NaCl}$ & 1.00 & -9.09 & $4.90^{\mathrm{b}}$ & 113.04 & 0.32 & -20.00 & 12.93 & 6.77 & $8.65^{a b}$ & -28.45 & 24.04 & 44.21 & 31.56 & 7.57 \\
\hline $200 \mathrm{mM} \mathrm{NaCl}$ & 1.02 & -7.27 & $4.85^{b}$ & 110.87 & 0.39 & -2.50 & 11.89 & -1.82 & $11.00^{\mathrm{b}}$ & -9.02 & 23.87 & 43.19 & 32.57 & 11.01 \\
\hline $3 \mathrm{~Gy}+100 \mathrm{mM} \mathrm{NaCl}$ & 1.03 & -6.36 & $4.69^{b}$ & 103.91 & 0.41 & 2.50 & 12.74 & 5.20 & 7.50 & -37.97 & 13.98 & -16.14 & 30.89 & 5.28 \\
\hline $3 \mathrm{~Gy}+200 \mathrm{mM} \mathrm{NaCl}$ & 1.02 & -7.27 & 3.22 & 40.00 & 0.38 & -5.00 & 10.92 & -9.83 & $9.39^{b}$ & -22.33 & 21.87 & 31.19 & 33.30 & 13.50 \\
\hline $5 \mathrm{~Gy}+100 \mathrm{mM} \mathrm{NaCl}$ & 1.02 & -7.27 & 3.23 & 40.43 & 0.39 & -2.50 & 10.04 & -17.09 & 7.99 & -33.91 & 20.45 & 22.68 & $30.28^{a b}$ & 3.20 \\
\hline $5 \mathrm{~Gy}+200 \mathrm{mM} \mathrm{NaCl}$ & 1.07 & -2.73 & $3.18^{b}$ & 38.26 & 0.37 & -7.50 & 10.08 & -16.76 & 10.00 & -17.29 & 16.75 & 0.48 & $40.06^{\mathrm{b}}$ & 36.53 \\
\hline
\end{tabular}

Values are mean of three experiments $\pm \mathrm{SE}$; letters are designating the significant difference between samples and control group. 


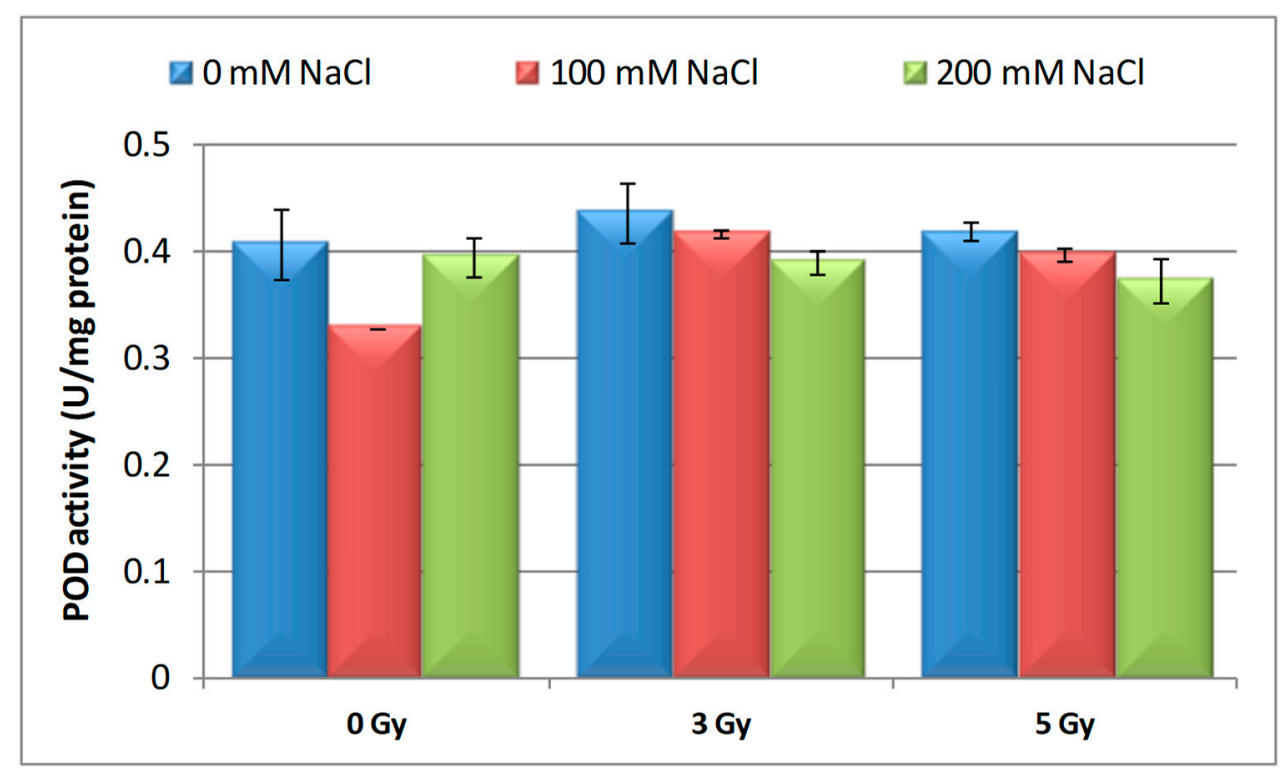

Figure 4. Effect of proton beam irradiation doses on the POD activity in 16-days-old seedlings Hordeum vulgare as response to salt stress.

The generation of reactive oxygen species (ROS) can be induced by diverse abiotic stresses, such as salt, drought, heat, or heavy metal stress. ROS is a collective term used both for free radicals, like hydroxyl radical $(\bullet \mathrm{OH})$, superoxide anion $\left(\bullet \mathrm{O}_{2}^{-}\right)$, and alkoxy radicals $(\mathrm{RO} \bullet)$ as well as non-radical (molecular) forms such as hydrogen peroxide $\left(\mathrm{H}_{2} \mathrm{O}_{2}\right)$ and singlet oxygen $\left({ }^{1} \mathrm{O}_{2}\right)[58,59]$. Salinity-mediated hyperosmotic and hyperionic stress causes supplementary stress in plants, well-known as oxidative stress. This phenomenon is due to the disruption of the balance between ROS generation and its decrease by various antioxidants [60].

In order to cope with different types of environmental stresses, plants have developed various strategies. Thus, in response to ROS overproduction, plant cells activate endogenous enzymatic defense mechanisms against oxidative stress [61]. To maintain the balance of ROS levels, plants synthesize various enzymatic and non-enzymatic antioxidants that equilibrate but do not eliminate ROS, because complete eradication of ROS means the loss of a second important messenger in intracellular signaling cascades [62]. The ROS excess can lead to irreparable metabolic dysfunction and even cell death by direct attack of photosynthetic pigments, membrane lipids, proteins, and nucleic acids [63].

Induction of the antioxidant defense system is an important mechanism of stress response after irradiation and salinity treatment. Thus, it has been shown that gamma rays can interact directly with different cellular components by crossing multiple levels to reach membranes, proteins, and nucleic acids [64]. Several studies have reported an intensification of antioxidant enzymes activity in plants in response to various ionizing radiation treatments $[18,38,65]$.

Our research revealed that CAT had more intense activity than SOD, both in single and combined treatments applied to barley seeds and seedlings. These results are in accordance with those of Reference [65] on the irradiated and non-irradiated Arabidopsis sp. samples. The authors established that low-dose gamma irradiations induced a significant increase in the antioxidant enzymes POD, SOD, and CAT activity in Arabidopsis sp seedlings. SOD, which forms the first and most important line of antioxidant defense, catalyzes the rapid dismutation of $\bullet \mathrm{O}_{2}{ }^{-}$to produce $\mathrm{H}_{2} \mathrm{O}_{2}$. However, the $\mathrm{H}_{2} \mathrm{O}_{2}$ produced by SOD is toxic to plant cells and may be broken down into $\mathrm{H}_{2} \mathrm{O}$ and $\mathrm{O}_{2}$ by the action of CAT or POD [66]. Baek et al. [49] showed that the activity of some antioxidant enzymes, such as superoxide dismutase (SOD) and ascorbate peroxidase (APX), rose by increasing $\mathrm{NaCl}$ concentrations, and the irradiated groups had higher SOD and APX activity compared to the non-irradiated ones. The alleviation action was similar in both rice cultivars tested. 
Antioxidant enzymes activity in seeds and young leaves of colored wheat seedling had diverse responses after acute (dose rate: $12.5 \mathrm{~Gy} / \mathrm{h}, 37.5 \mathrm{~Gy} / \mathrm{h}$, and $62.5 \mathrm{~Gy} / \mathrm{h}$ ) and chronic (dose rate: $0.298 \mathrm{~Gy} / \mathrm{h}$, $0.893 \mathrm{~Gy} / \mathrm{h}$, and $1.488 \mathrm{~Gy} / \mathrm{h}$ ) exposure times (two weeks) [67]. The authors mention that POD activity in seeds was higher after chronic irradiation, and CAT activity was similar to that in control seeds, but lower after acute irradiation. SOD activity did not change significantly in the case of the two types of irradiation. The POD activity in seedlings showed a similar pattern in both applied treatments and CAT activity increased after chronic irradiation. Chronic irradiation induced higher SOD activity in colored wheat seedlings.

As far as our results are concerned, the differences observed in CAT and POD enzyme activities can be argued by the affinity of both enzymes for $\mathrm{H}_{2} \mathrm{O}_{2}$. Even though both enzymes are stimulated by $\mathrm{H}_{2} \mathrm{O}_{2}$ accumulation, CAT is activated at higher concentrations while POD is triggered at low $\mathrm{H}_{2} \mathrm{O}_{2}$ levels [68].

Zaka et al. [69] explained that after the application of low doses of radiation, the enzymatic antioxidants activity has increased due to increased regulation of the corresponding genes to provide cells resistance. At high doses, cellular oxidative stress plays a significant role in cell damage caused by ionizing radiation, and antioxidants can have a protective effect at these doses [70].

The treatment with proton beams reduced chlorophyll content in the soybean seedlings [56]. Moreover, the authors mention that the main antioxidant enzymes, SOD and POD, have similar pattern of activity in two soybean cultivars, with the effect being more intense at low doses (55 Gy).

\subsection{Effect of Salinity and Proton Irradiation on MDA Content of Barley Seedling}

MDA is the end product of lipid peroxidation and represents one of the most illustrative tests for assessing oxidative damage in plant tissues, being a major indicator of oxidative stress [71].

To see whether irradiation with proton beam could mitigate the oxidative stress induced by salinity in barley seedlings, MDA content was measured. As shown in Figure 5, MDA activity decreased both at 3 and 5 Gy irradiated barley seeds by a rate of $12.55 \%$ and $10.41 \%$, compared to the control. Moreover, a gradual decrease in MDA content was observed with the increase of $\mathrm{NaCl}$ concentration in the single saline solution application. The highest MDA level (stimulation rate over $6 \%$ ) was registered in seeds with $100 \mathrm{mM} \mathrm{NaCl}$ exposure. The seeds irradiated with $3 \mathrm{~Gy}$ and germinated in the presence of $100 \mathrm{mM} \mathrm{NaCl}$ revealed the increase of MDA level (12.74 $\mathrm{nmol} \mathrm{mg}^{-1}$ protein), while $200 \mathrm{mM} \mathrm{NaCl}$ stress induced a decline (10.92 $\mathrm{nmol} \mathrm{mg}^{-1}$ protein) of this enzyme activity, compared to the control (12.11 nmol mg ${ }^{-1}$ proteins). Both saline concentrations (100 mM and $200 \mathrm{mM}$ ) applied to seeds after irradiation with 5 Gy determined the inhibition of MDA content by $17 \%$ and $16 \%$, respectively.

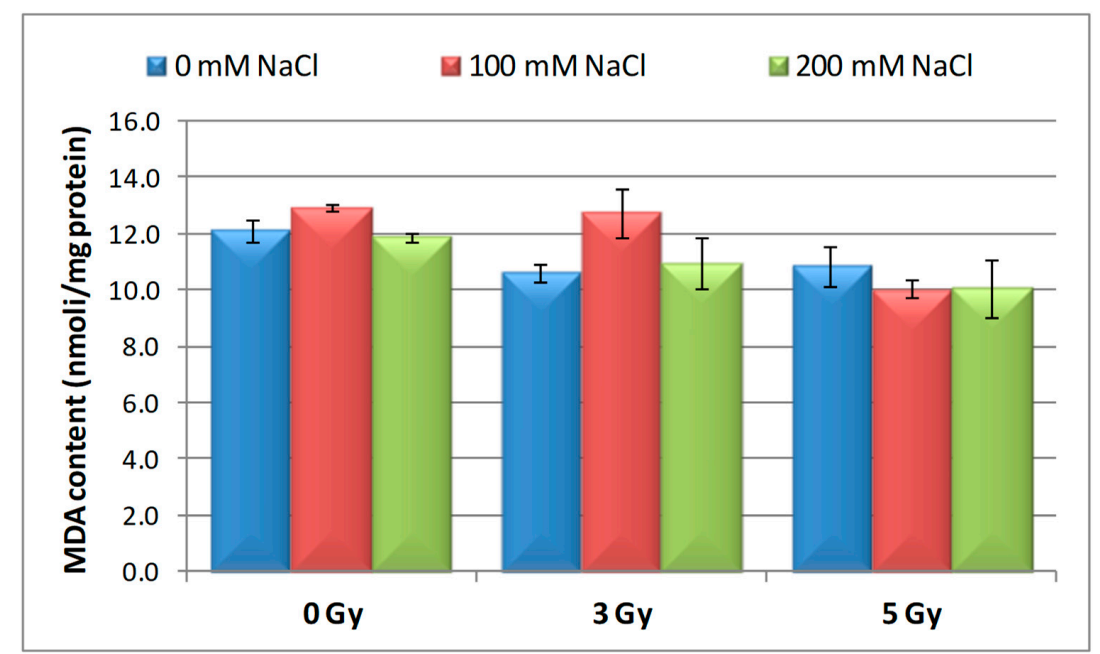

Figure 5. Effect of proton beam irradiation doses on the malondialdehyde (MDA) content in 16-days-old seedlings Hordeum vulgare as response to salt stress. 
Our results showed that $5 \mathrm{~Gy}$ irradiation can effectively reduce the oxidative stress of $100 \mathrm{mM}$ and $200 \mathrm{mM} \mathrm{NaCl}$ seedlings, indicated by lower levels of MDA in the irradiated material than in non-irradiated seedlings, as response to both saline stresses.

After proton beam pretreatment ( 3 and 5 Gy), the SOD activity in barley seedlings was antagonistic to the MDA content, the main role of SOD being as a scavenger for radicals superoxide, having as effect inactivation of CAT and POD activity [56].

Recent studies [72] have demonstrated that pretreatments with gamma irradiation caused a decrease of MDA activity in Vicia sativa L. Using high doses of irradiation (50-400 Gy, corresponding to $57 \mathrm{MeV}$ ), Reference [47] revealed an increase of MDA content in soybean plants irradiated with proton beam, without a direct dose-effect relationship.

Lipid peroxidation induced by free radicals can generally determine an increase in membrane permeability or a loss of its integrity, leading to a higher level of MDA [73]. Thus, the changes in MDA activity can serve as an index for determining the level of membrane permeability and integrity. Under conditions of salt stress, the cell membrane is damaged as a response to a high level of lipid peroxidation [74]. Although MDA typically increases when plants are subjected to salt stress, MDA level improved by up to 3-7\% in rice seedling using 4 Gy gamma-irradiated seeds and germinated in presence of $40 \mathrm{mM} \mathrm{NaCl}$ [49].

Our results are similar to those of Song et al. [75] who, using resistant (ST-salt tolerance) and sensitive (WT-weak tolerance) mutant rice lines, found an increase in MDA level due to prolonged salt stress, with this augmentation being higher in the WT lines than in the ST plants.

\subsection{Effect of Salinity and Proton Irradiation on Soluble Protein Content of Barley Seedling}

Different changes in soluble protein content of barley samples were observed in non-irradiated ( 0 Gy) and irradiated ( 3 and 5 Gy) seedling, with and without $\mathrm{NaCl}$-associated treatment $(100 \mathrm{mM}$ and $200 \mathrm{mM}$ ). Thus, after irradiation with $3 \mathrm{~Gy}$, the protein content was lower by $6.58 \%$ than the control, and the 5 Gy dose determined an insignificant increase in this parameter (by $2.98 \%$ ), as shown in Figure 6. Our results proved that the soluble protein content rose with increasing $\mathrm{NaCl}$ concentrations. Seeds irradiated with both 3 Gy and 5 Gy showed an increase in protein content in the presence of $200 \mathrm{mM}$ compared to $100 \mathrm{mM} \mathrm{NaCl}$. Interesting enough, when the $5 \mathrm{~Gy}$ irradiated seeds were germinated in the presence of $200 \mathrm{mM} \mathrm{NaCl}$, the soluble protein content was $36.53 \%$ higher than control.

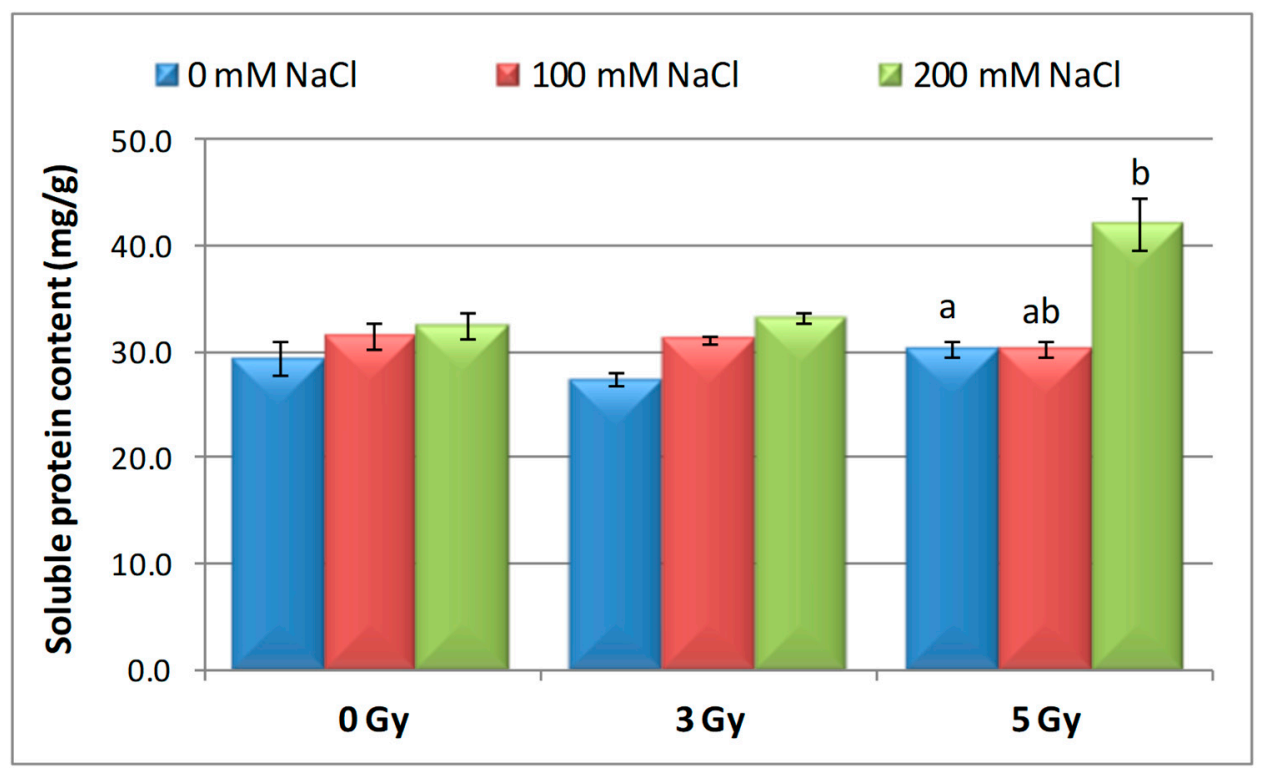

Figure 6. Effect of proton beam irradiation doses on the protein content in 16-days-old seedlings Hordeum vulgare as response to salt stress. Values are mean of three experiments $\pm \mathrm{SE}$; letters are designating the significant difference between samples and control group. 
The increase in the content of soluble protein is one of the protective mechanisms of the plants against gamma irradiation damages, which correlates with increasing doses [76]. Thus, Štajner et al. [77] established that gamma irradiation (1-10 kGy) of soybeans has induced insignificant changes in the soluble protein content. Similar results were obtained by Byun et al. [78] who mentioned that gamma irradiation, up to $10 \mathrm{kGy}$, did not induce significant reduction of minerals, nitrogenous constituents, sugars, and proteins content. On the other hand, Hanafy and Akladious [40] reported that high dose of gamma radiation (400 Gy) led to a significant decrease in the total protein contents in fenugreek plants as compared to untreated control plants.

\subsection{Effect of Salinity and Proton Irradiation on Content of Total Polyphenol and Flavonoids in Barley Seedlings}

Apart from antioxidant enzymes, small molecular weight and non-enzymatic antioxidants are also involved in the protection of the intracellular components against the ROS.

In our research, proton beam irradiation ( 3 and 5 Gy) applied alone led to a marked decline in polyphenols content of barley seedlings (Figure 7) compared to the control ( $18 \%$ and $59 \%$, respectively). The decrease was much more significant at $5 \mathrm{~Gy}$. The highest increase of polyphenols level (44.23 and $43.18 \%$, respectively) was observed when barley seeds germinated only in the presence of $\mathrm{NaCl}$ concentrations (100 and $200 \mathrm{mM}$ ). The application of $100 \mathrm{mM} \mathrm{NaCl}$ on the proton beam irradiated 3 Gy seeds showed a decrease (by 16\%) in the polyphenol content while the treatment with $200 \mathrm{mM}$ $\mathrm{NaCl}$ determined an increase by $31 \%$, compared to the control. We mention that the situation was exactly the opposite for the seeds irradiated with $5 \mathrm{~Gy}$ and grown under $100 \mathrm{mM}$ and $200 \mathrm{mM} \mathrm{NaCl}$ conditions. Due to their hydroxyl groups with scavenging ability, phenolics are important constituents and may hence contribute directly to the antioxidant action [79].

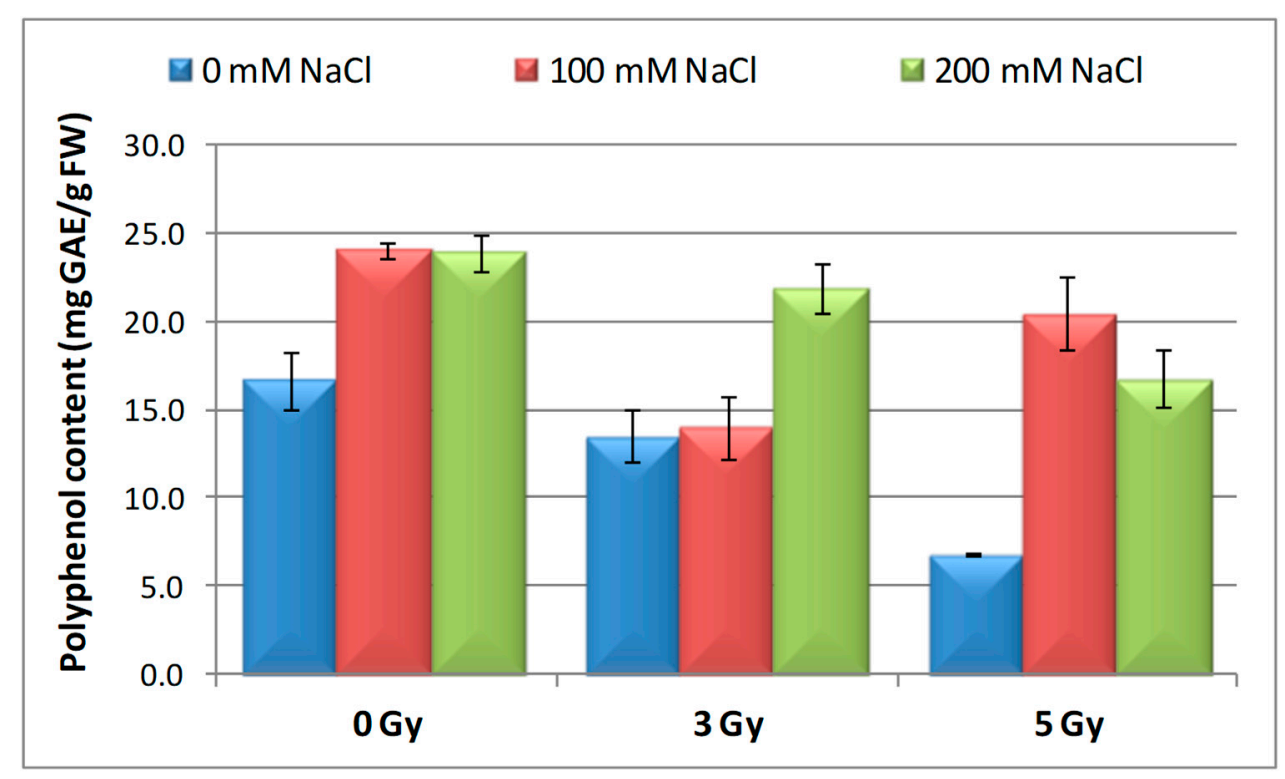

Figure 7. Effect of proton beam irradiation doses on the polyphenol content in 16-days-old seedlings Hordeum vulgare as response to salt stress.

Low doses of radiation stimulate the accumulation of antioxidants, and synthesis can be induced by an increased gene expression and intensification of monomers degradation of some polyphenols. The high-dose radiation reduces the content of non-enzymatic and enzymatic antioxidants because the plant loses its ability to defeat the oxidative damage $[53,80]$.

Regarding the flavonoids content (Figure 8), the results revealed increasing values (by $66 \%$ and by $10 \%$, respectively) only in the case of seeds irradiated with proton beam (3 Gy and 5 Gy), compared with the control. Both saline treatments showed a decrease in the level of flavonoids in barley seedlings, with $28.43 \%$ in the case of $100 \mathrm{mM} \mathrm{NaCl}$ and $9.04 \%$ in $200 \mathrm{mM} \mathrm{NaCl}$ lower than the control. Moreover, 
when the seeds irradiated with the proton beam were germinated in saline conditions, the decrease in flavonoids content was more intense at $100 \mathrm{mM} \mathrm{NaCl}$, compared to the control, with 37.97\% and $33.91 \%$ in the case of irradiation with $3 \mathrm{~Gy}$ and $5 \mathrm{~Gy}$, respectively. This reduction was lower at a saline stress of $200 \mathrm{mM}$ registering a decrease rate of $22.33 \%$ and $17.29 \%$ (for $3 \mathrm{~Gy}$ and $5 \mathrm{~Gy}$ ). Moreover, when the proton beam-irradiated seeds were germinated on saline conditions, it maintained the decrease of this parameter higher at $100 \mathrm{mM} \mathrm{NaCl}$ (5.26\% and 3.18\% for $3 \mathrm{~Gy}$ and $5 \mathrm{~Gy}$ ) and lower at $200 \mathrm{mM}$ $\mathrm{NaCl}(13.48 \%$ and $51.91 \%$ for $3 \mathrm{~Gy}$ and $5 \mathrm{~Gy})$.

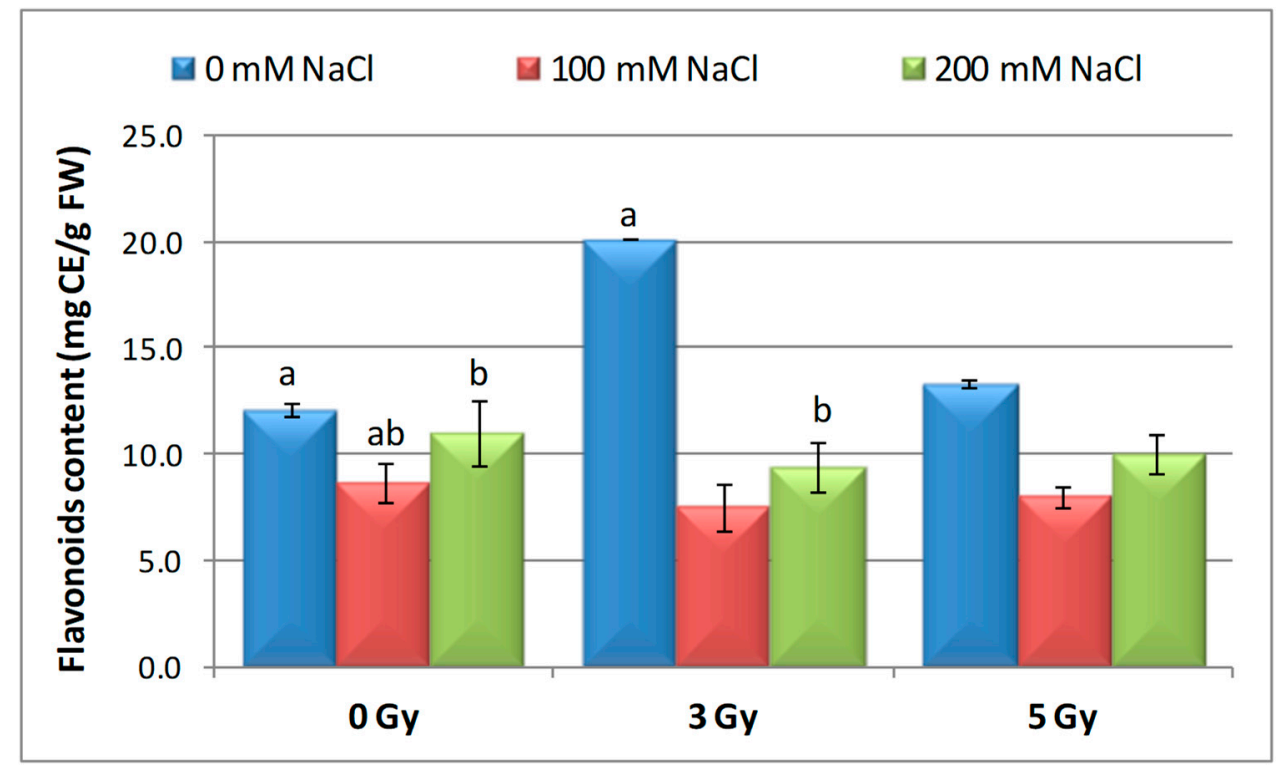

Figure 8. Effect of proton beam irradiation doses on the flavonoids content in 16-days-old seedlings Hordeum vulgare as a response to salt stress. Values are mean of three experiments $\pm \mathrm{SE}$; letters are designating the significant difference between samples and control group.

Flavonoids represent one of the secondary metabolites with significant antioxidant and chelating properties, which are present in plants and have a significant role in the reduction of damage induced by different types of irradiation.

Exposure of fenugreek seeds to gamma radiation (25, 50, 100, 200, and $400 \mathrm{~Gy})$ induced an increase in the phenolic and flavonoids content, especially at $100 \mathrm{~Gy}$, both in M1 and M2 generation. Instead, the high dose of $400 \mathrm{~Gy}$ decreased all physiological and biochemical parameters analyzed [40]. Other studies [81] signaled that gamma irradiation $(2,4,8,16,32$, and $64 \mathrm{k}$-rad) associated with bio-fertilizer treatments have increased the total level of flavonoids in dill seedlings, with the highest content recorded at $64 \mathrm{k}$-rad. Furthermore, the flavonoids accumulation depends on the analyzed parts of the plant (umbels $>$ vegetative plant $>$ flowering plant $>$ leaves + stems in the flowering stage).

\section{Conclusions}

The impact of synergistic exposure to proton beam irradiation of barley seeds and salinity stress was discussed in relation to the potential of enzymatic and non-enzymatic antioxidants and soluble protein content, as well as assimilatory pigment level.

The 3 Gy proton beam irradiation resulted in lower assimilatory pigments content compared to the control, even if the germination occurred in 100 or $200 \mathrm{mM} \mathrm{NaCl}$ conditions. Out of all the antioxidant enzymes that were part of the study (SOD, CAT, and POD) only CAT activity increased in irradiated seeds germinated under salinity conditions, which indicates the activation of antioxidant defense. The MDA content of seeds germinated on $200 \mathrm{mM} \mathrm{NaCl}$ stress dropped as the irradiation doses increased. The 3 and 5 Gy proton beam pretreatment of barley seeds, associated with $200 \mathrm{mM}$ $\mathrm{NaCl}$ exposure, revealed a high soluble protein content in the 16-days-old seedlings. When compared 
to the control, the total polyphenol amount was lower only when the seeds germination was performed in the presence of $100 \mathrm{mM} \mathrm{NaCl}$, while the flavonoids content was inhibited regardless of the applied salinity level. Based on the growth rate, the study suggests that $3 \mathrm{~Gy}$ proton beam irradiation of barley seeds can alleviate the harmful action of $100 \mathrm{mM} \mathrm{NaCl}$ stress, as proved by a $1.95 \%$ increase seedlings growth rate as compared to the control.

Author Contributions: Conceptualization, L.O., G.V., M.-N.G., D.G., and I.C.; methodology, L.O., G.V., and D.G.; software, M.-N.G. and C.-T.M.; investigation, L.O., G.V., M.-N.G., D.G., and I.C.; writing-original draft preparation, L.O., G.V., M.-N.G., D.G., and I.C.; statistical processing, C.-T.M. All authors have read and agreed to the published version of the manuscript.

Funding: This research was funded by the Romanian Ministry of Education and Research through the NUCLEU program (Contract no. 25N/2019/Project code 19-270301), Contract no. 22PFE/2018, and the APC was funded by Ministry of Research and Innovation within Program 1-Development of the national RD system, Subprogram 1.2-Institutional Performance-RDI excellence funding projects, Contract no.34PFE/19.10.2018.

Conflicts of Interest: The authors declare no conflict of interest.

\section{References}

1. Akar, T.; Avci, M.; Dusunceli, F. Barley: Post-Harvest Operations; INPhO-Post-Harvest Compendium; Food and Agriculture Organization of the United Nations, AGST/FAO: Ankara, Turkey, 2004; pp. 1-60.

2. Jebor, M.A.; Al-Saadi, A.; Behjet, R.H.; Al-Terehi, M.; Zaidan, H.K.; Al-Saadi, M.A.K. Characterization and antimicrobial activity of barley grain (Hordeum vulgare) extract. Int. J. Curr. Microbiol. Appl. Sci. 2013, 2, $41-48$.

3. Gupta, B.; Huang, B. Mechanism of Salinity Tolerance in Plants: Physiological, Biochemical, and Molecular Characterization. Int. J. Genom. 2014, 2014, 701596. [CrossRef]

4. Storey, R.; Wyn Jones, R.G. Salt stress and comparative physiology in the gramineae. I. Ion relations of two salt and water stressed barley cultivars, California Mariout and Arimar. Aust. J. Plant Physiol. 1978, 5, 801-816. [CrossRef]

5. Mallek-Maalej, E.; Dakhli, R.; Abdi, N.; Slama, A.; Salem, M.B. Evaluation of the Effect of Salt Stress on Some Physiological and Agronomic Traits in Tunisian Durum Wheat Varieties. Eur. J. Sci. Res. 2015, 130, 88-100.

6. Costa, S.F.; Martins, D.; Agacka-Mołdoch, M.; Czubacka, A.; de Sousa Araújo, S. Strategies to Alleviate Salinity Stress in Plants in Salinity Responses and Tolerance in Plants. In Salinity Responses and Tolerance in Plants; Kumar, V., Wani, S.H., Suprasanna, P., Tran, L.S.P., Eds.; Springer International Publishing AG: Berlin/Heidelberg, Germany, 2018; Volume 1, pp. 307-337.

7. Abbas, R.; Rasul, S.; Aslam, K.; Baber, M.; Shahid, M.; Mubeen, F.; Naqqash, T. Halotolerant PGPR: A hope for cultivation of saline soils. J. King Saud Univ. Sci. 2019, 31, 1195-1201. [CrossRef]

8. Kabar, K. Alleviation of salinity stress by plant growth regulators on seed germination. J. Plant Physiol. 1987, 128, 179-183. [CrossRef]

9. Javid, M.G.; Sorooshzadeh, A.; Moradi, F.; Sanavy, S.A.M.M.; Allahdadi, I. The role of phytohormones in alleviating salt stress in crop plants. Aust. J. Crop. Sci. 2011, 5, 726-734.

10. Shaddad, M.A.K.; Abd El-Samad, H.M.; Mostafa, D. Role of gibberellic acid (GA3) in improving salt stress tolerance of two wheat cultivars. Int. J. Plant Physiol. Biochem. 2013, 5, 50-57.

11. Ilangumaran, G.; Smith, D.L. Plant Growth Promoting Rhizobacteria in Amelioration of Salinity Stress: A Systems Biology Perspective. Front. Plant Sci. 2017, 8, 1768. [CrossRef]

12. Oprica, L.; Stefan, M. Evaluation of morphological and biochemical parameters of soybean seedlings induced by saline stress. Rom. Biotechnol. Lett. 2014, 19, 9615-9624.

13. Macovei, A.; Garg, B.; Raikwar, S.; Balestrazzi, A.; Carbonera, D.; Buttafava, A.; Bremont, J.F.; Gill, S.S.; Tuteja, N. Synergistic exposure of rice seeds to different doses of $\gamma$-ray and salinity stress resulted in increased antioxidant enzyme activities and gene-specific modulation of TC-NER pathway. Biomed. Res. Int. 2014, 170, 780-787. [CrossRef] [PubMed]

14. Dehpour, A.A.; Gholampour, M.; Rahdary, P.; Jafari, T.M.R.; Hamdi, S.M.M. Effect of gamma irradiation and salt stress on germination, callus, protein and proline in rice (Oryza sativa L.). Iran. J. Plant Physiol. 2011, 1, $251-256$. 
15. Rejili, M.; Telahigue, D.; Lachiheb, B.; Mrabet, A.; Ferchichi, A. Impact of gamma radiation and salinity on growth and $\mathrm{K}^{+} / \mathrm{Na}^{+}$balance in two populations of Medicago sativa (L.) cultivar Gabe. Prog. Nat. Sci. Mater. 2008, 18, 1095-1105. [CrossRef]

16. Ahmed, A.H.A.; Ghalab, A.R.M.; Hussein, O.S.; El-Hefny, A.M. Effect of Gamma Rays and Salinity on Growth and Chemical Composition of Ambrosia maritima L. Plants. J. Radiat. Res. Appl. Sci. 2011, 4, 1139-1162.

17. El-Beltagi, H.S.; Mohamed, H.I.; Mohammed, A.H.M.A.; Zaki, L.M.; Mogazy, A.M. Physiological and biochemical effects of $\gamma$-irradiation on cowpea plants (Vigna sinensis) under salt stress. Notulae Botanicae Horti Agrobotanici Cluj-Napoca 2013, 41, 104-114. [CrossRef]

18. Geng, X.; Zhang, Y.; Wang, L.; Yang, X. Pretreatment with High-Dose Gamma Irradiation on Seeds Enhances the Tolerance of Sweet Osmanthus Seedlings to Salinity Stress. Forests 2019, 10, 406. [CrossRef]

19. Hamideldin, N.; Eliwa, N.E.; Hussein, O.S. Role of jasmonic acid and gamma radiation in alleviating salt stress in moringa. Int. J. Agric. Biol. 2017, 19, 93-98. [CrossRef]

20. Jan, S.; Parween, T.; Siddiqi, T.O.; Mahmooduzzafar, N. Effect of gamma radiation on morphological, biochemical and physiological aspects of plants and plant products. Environ. Rev. 2012, 20, 17-39. [CrossRef]

21. Ling, A.P.K.; Ung, Y.C.; Hussein, S.; Harun, A.R.; Tanaka, A.; Yoshihiro, H. Morphological and biochemical responses of Oryza sativa L. (cultivar MR219) to ion beam irradiation. J. Zhejiang Univ. Sci. B 2013, 14, 1132-1143. [CrossRef]

22. Lee, J.H.; Lee, A.R.; Kwon, S.W. Effect of proton beam irradiation on M1 seeds and seedling growth in rice. Plant Breed. Biotechnol. 2015, 3, 384-388. [CrossRef]

23. Lee, Y.M.; Jo, Y.D.; Lee, H.J.; Kim, Y.S.; Kim, D.S.; Kim, J.B.; Kang, S.Y.; Kim, S.H. DNA damage and oxidative stress induced by proton beam in Cymbidium hybrid. Hortic. Environ. Biotechnol. 2015, 56, 240-246. [CrossRef]

24. Salvi, S.; Druka, A.; Milner, S.G.; Gruszka, D. Induced Genetic Variation, TILLING and NGS-Based Cloning. In Biotechnological Approaches to Barley Improvement; Kumlehn, J., Stein, N., Eds.; Springer: Berlin/Heidelberg, Germany, 2014; Volume 69, pp. 287-310.

25. Khazaei, H.; Mäkelä, P.S.A.; Stoddard, F.L. Ion beam irradiation mutagenesis in rye (Secale cereale L.), linseed (Linum usitatissimum L.) and faba bean (Vicia faba L.). Agric. Food Sci. 2018, 27, 146-151. [CrossRef]

26. Kim, W.J.; Ryu, J.; Im, J.; Kim, S.H.; Kang, S.Y.; Lee, J.H.; Jo, H.S.; Ha, B.K. Molecular characterization of proton beam-induced mutations in soybean using genotyping-by-sequencing. Mol. Genet. Genom. 2018, 293, 1169-1180. [CrossRef] [PubMed]

27. Kumar, V.; Vishwakarma, G.; Chauhan, A.; Shitre, A.; Das, B.K. Use of Proton Beam as a Novel Tool for Mutations in Rice. BARC Newsl. 2018, 366, 5-9.

28. Bhat, N.N.; Sapra, B.K.; Gupta, S.K. Proton Beam Set-up for Radiobiological Studies. BARC Newsl. 2015, 346, 5-7.

29. Deoli, N.T.; Hasenstein, K.H. Irradiation effects of MeV protons on dry and hydrated Brassica rapa seeds. Life Sci. Space Res. 2018, 19, 24-30. [CrossRef]

30. Lichtenthaler, H.K. Chlorophyll and carotenoids: Pigments of photosynthetic bio-membranes. In Methods Enzymology; Packer, L., Douce, R., Eds.; Academic Press: London, UK, 1987; Volume 641, pp. 350-382.

31. Hodges, D.M.; Delong, J.M.; Forney, C.F.; Prange, R.K. Improving the thiobarbituric acid-reactive-substances assay for estimating lipid peroxidation in plant tissues containing anthocyanin and other interfering compounds. Planta 1999, 207, 604-611. [CrossRef]

32. Singleton, V.L.; Orthofer, R.; Lamuela-Raventós, R.M. Analysis of total phenols and other oxidation substrates and antioxidants by means of Folin-Ciocalteu reagent. Methods Enzymol. 1999, 299, 152-178.

33. Dewanto, V.; Wu, X.; Adom, K.K.; Liu, R.H. Thermal processing enhances the nutritional value of tomatoes by increasing total antioxidant activity. J. Agric. Food Chem. 2002, 50, 3010-3014. [CrossRef]

34. Dhindsa, R.A.; Plumb, D.P.; Thorpe, T.A. Leaf senescence, correlated with increased permeability and lipid peroxidation, and decreased levels of superoxide dismutase and catalase. Exp. Bot. 1981, 126, 93-101. [CrossRef]

35. Ranieri, A.; Petacco, F.; Castagna, A.; Soldatini, G.F. Redox state and peroxidase system in sunflower plants exposed to ozone. Plant Sci. 2000, 159, 159-167. [CrossRef]

36. Sinha, A.K. Colorimetric assay of catalase. Anal. Biochem. 1972, 47, 389-394. [CrossRef]

37. Bradford, M.M. A Rapid and Sensitive Method for the Quantitation of Microgram Quantities of Protein Utilizing the Principle of Protein-Dye Binding. Anal. Biochem. 1976, 72, 248-254. [CrossRef] 
38. Wi, S.G.; Chung, B.Y.; Kim, J.S.; Baek, M.H.; Lee, J.W.; Kim, Y.S. Effects of gamma irradiation on morphological changes and biological responses in plants. Micron 2007, 38, 553-564. [CrossRef]

39. Singh, B.; Datta, P.S. Gamma irradiation to improve plant vigour, grain development, and yield attributes of wheat. Radiat. Phys. Chem. 2010, 79, 139-143. [CrossRef]

40. Hanafy, R.S.; Akladious, S.A. Physiological and molecular studies on the effect of gamma radiation in fenugreek (Trigonella foenum-graecum L.) plants. J. Genet. Eng. Biotechnol. 2018, 16, 683-692. [CrossRef]

41. Koing, A.L.P.; Lai, A.G.; Hussein, S.; Harun, A.R. Physiological responses of Orthosiphon stamineus plantlets to gamma irradiation. Am. Eurasian J. Sustain. Agric. 2008, 2, 135-149.

42. Qin, H.L.; Wang, Y.G.; Xue, J.M.; Miao, Q.; Ma, L.; Mei, T.; Zhang, W.M.; Guo, W.; Wang, J.Y.; Gu, H.Y. Biological effects of protons targeted to different ranges in Arabidopsis seeds. Int. J. Radiat. Biol. 2007, 83, 301-308. [CrossRef]

43. Kim, S.K.; Park, S.Y.; Kim, K.R.; Shin, J.H.; Kim, S.Y.; Kim, H.Y.; Lee, I.J. Effect of proton beam irradiation on germination, seedling growth, and pasting properties of starch in rice. J. Crop. Sci. Biotechnol. 2012, 15, 305-310. [CrossRef]

44. Chauhan, A.; Kumar, V.; Iyer, P.R.; Vishwakarma, G.; Nair, J.P.; Surendran, P.; Sparrow, H.; Gupta, A.K.; Shitre, A.S.; Shinde, A.K.; et al. Effect of proton beam irradiation on survival and seedling growth parameters of Indian rice (Oryza sativa L.) variety 'Indira Barani Dhan 1'. Electron. J. Plant Breed. 2019, 10, 490-499. [CrossRef]

45. Bae, C.H.; Lyu, J.I.; Sarantuya, G.; Chai, J.S.; Kim, J.H.; Yahng, T.G.; Lee, M.Y.; Yang, D.C. Efects of Proton Beam Iradiation on Germination and Growth of Tabacco and Rice Plants. Korean J. Plants Res. 2005, 18, 462-469.

46. Gonzalez, M.C.; Perez, N.; Cristo, E. GINES: A first rice mutant obtained by proton irradiation. Cult. Trop. $2009,30,9$.

47. Im, J.; Kim, W.J.; Kim, S.H.; Ha, B.K. Effects of proton beam irradiation on seed germination and growth of soybean, (Glycine max L. Merr.). J. Korean Phys. Soc. 2017, 71, 752-757. [CrossRef]

48. Oprica, L.; Grigore, M.M.; Vochita, G. Impact of saline stress on growth and biochemical indices of Calendula officinalis seedlings. Rom. Biotechnol. Lett. 2015, 20, 11007-11017.

49. Baek, M.H.; Kim, J.H.; Chung, B.Y.; Kim, J.S.; Lee, I.S. Alleviation of salt stress by low dose $\gamma$-irradiation in rice. Biol. Plant. 2005, 49, 273-276. [CrossRef]

50. Malanga, G.; Calmanovici, G.; Puntarulo, S. Oxidative damage to chloroplasts from Chlorella vulgaris exposed to ultraviolet-B radiation. Physiol. Plant. 1997, 101, 455-462. [CrossRef]

51. Kumar, S.G.; Lakshmi, A.; Madhusudhan, K.V.; Ramanjulu, S.; Sudhakar, C. Photosynthesis parameters in two cultivars of mulberry differing in salt tolerance. Photosynthetica 1999, 36, 611-616. [CrossRef]

52. Sultana, N.; Ikeda, T.; Itoh, R. Effects of $\mathrm{NaCl}$ salinity on photosynthesis and dry matter accumulation in developing rice grain. Environ. Exp. Bot. 1999, 42, 211-220. [CrossRef]

53. De Micco, V.; Paradiso, R.; Aronne, G.; De Pascale, S.; Quarto, M.; Arena, C. Leaf anatomy and photochemical behaviour of Solanum lycopersicum L. plants from seeds irradiated with low-LET ionising radiation. Sci. World J. 2014, 2014, 428141. [CrossRef]

54. Kim, S.H.; Song, M.; Lee, K.J.; Hwang, S.G.; Jang, C.S.; Kim, J.B.; Kim, S.H.; Ha, B.K.; Kang, S.Y.; Kim, D.S. Genome-wide transcriptome profiling of ROS scavenging and signal transduction pathways in rice (Oryza sativa L.) in response to different types of ionizing radiation. Mol. Biol. Rep. 2012, 39, 11231-11248.

55. Kalimullah, M.; Gaikwad, J.U.; Thomas, S.; Sarma, A.; Vidyasagar, P.B. Assessment of $1 \mathrm{H}$ heavy ion irradiation induced effects in the development of rice (Oryza sativa L.) seedlings. Plant. Sci. 2003, 165, 447-454. [CrossRef]

56. Im, J.; Ko, J.; Kim, H.Y.; Ha, B.K. Biochemical Responses of Soybean (Glycine max L. Merr.) to Proton Beam Irradiation. Plant Breed. Biotechnol. 2017, 5, 97-105. [CrossRef]

57. Taibia, K.; Taibi, F.; Abderrahim, L.A.; Ennajah, A.; Belkhodja, M.; Muletd, J.M. Effect of salt stress on growth, chlorophyll content, lipid peroxidation and antioxidant defense systems in Phaseolus vulgaris L. S. Afr. J. Bot. 2016, 105, 306-312. [CrossRef]

58. Vanhoudt, N.; Cuypers, A.; Vangronsveld, J.; Horemans, N.; Wannijn, J.; Van Hees, M.; Vandenhove, H. Study of biological effects and oxidative stress related responses in gamma irradiated Arabidopsis thaliana plants. Radioprotection 2011, 46, S401-S407. [CrossRef] 
59. Ozgur, A.; Uzilday, B.; Sekmen, A.H.; Turkan, I. Reactive oxygen species regulation and antioxidant defence in halophytes. Funct. Plant Biol. 2013, 40, 832-847. [CrossRef]

60. Gill, S.S.; Tuteja, N. Reactive oxygen species and antioxidant machinery in abiotic stress tolerance in crop plants. Plant Physiol. Biochem. 2010, 48, 909-930. [CrossRef] [PubMed]

61. Mittler, R.; Vanderauwera, S.; Gollery, M.; Van Breusegem, F. Reactive oxygen gene network of plants. Trends Plant Sci. 2004, 9, 490-498. [CrossRef]

62. Afzal, F.; Khurshid, R.; Ashraf, N.; Kazi, A.G. Reactive Oxygen Species and Antioxidants in Response to Pathogens and Wounding. In Oxidative Damage to Plants. Antioxidant Networks and Signaling; Ahmad, P., Ed.; Academic Press: London, UK, 2014; pp. 397-424.

63. Bailey-Serres, J.; Mittler, R. The roles of reactive oxygen species in plant cells. Plant Physiol. 2006, 141, 311. [CrossRef] [PubMed]

64. Kovács, E.; Keresztes, Á. Effect of gamma and UV-B/C radiation on plant cells. Micron 2002, 33, $199-210$. [CrossRef]

65. Qi, W.; Zhang, L.; Xu, H.; Wang, L.; Jiao, Z. Physiological and molecular characterization of the enhanced salt tolerance induced by low-dose gamma irradiation in Arabidopsis seedlings. Biochem. Biophys. Res. Commun. 2014, 450, 1010-1015. [CrossRef]

66. Arora, A.; Sairam, R.K.; Srivastava, G.C. Oxidative stress and antioxidative system in plants. Curr. Sci. 2002, 82, 1227-1238.

67. Hong, M.J.; Kim, D.Y.; Ahn, J.W.; Kang, S.Y.; Seo, Y.W.; Kim, J.B. Comparison of radiosensitivity response to acute and chronic gamma irradiation in colored wheat. Genet. Mol. Biol. 2018, 41, 611-623. [CrossRef] [PubMed]

68. Gechev, T.S.; Breusegem, F.V.; Stone, J.M.; Denev, I.; Laloi, C. Reactive oxygen species as signals that modulate plant stress responses and programmed cell death. Bioessays 2006, 28, 1091-1101. [CrossRef]

69. Zaka, R.; Vandecasteele, C.M.; Misset, M.T. Effects of low chronic doses of ionizing radiation on antioxidant enzymes and G6PDH activities in Stipa capillata Poaceae. J. Exp. Bot. 2002, 53, 1979-1987. [CrossRef] [PubMed]

70. Smith, J.T.; Willey, N.J.; Hancock, J.T. Low dose ionizing radiation produces too few reactive oxygen species to directly affect antioxidant concentrations in cells. Biol. Lett. 2012, 8, 594-597. [CrossRef] [PubMed]

71. Ayala, A.; Muñoz, M.F.; Argüelles, S. Lipid Peroxidation: Production, Metabolism, and Signaling Mechanisms of Malondialdehyde and 4-Hydroxy-2-Nonenal. Oxid. Med. Cell. Longev. 2014, 360438. [CrossRef]

72. Beyaz, R. Impact of gamma irradiation pretreatment on the growth of common vetch (Vicia sativa L.) seedlings grown under salt and drought stress. Int. J. Radiat. Biol. 2020, 96, 257-266. [CrossRef]

73. Dionisio-Sese, M.L.; Tobita, S. Antioxidant response of rice seedlings to salinity stress. Plant Sci. 1998, 135, 1-9. [CrossRef]

74. Katsuhara, M.; Otsuka, T.; Ezaki, B. Salt stress-induced lipid peroxidation is reduced by glutathione S-transferase, but this reduction of lipid peroxides is not enough for a recovery of root growth in Arabidopsis. Plant Sci. 2005, 169, 369-373. [CrossRef]

75. Song, J.Y.; Kim, D.S.; Lee, M.C.; Lee, K.J.; Kim, J.B.; Kim, S.H.; Ha, B.K.; Yun, S.J.; Kang, S.Y. Physiological characterization of gamma-ray induced salt tolerant rice mutants. Aust. J. Crop. Sci. 2012, 6, 421-429.

76. Al-Rumaih, M.M.; Al-Rumaih, M.M. Influence of ionizing radiation on antioxidant enzymes in three species of Trigonella. Am. J. Environ. Sci. 2008, 4, 151-156. [CrossRef]

77. Štajner, D.; Milošević, M.; Popović, B.M. Irradiation effects on phenolic content, lipid and protein oxidation and scavenger ability of soybean seeds. Int. J. Mol. Sci. 2007, 8, 618-627. [CrossRef]

78. Byun, M.; Kang, I.; Mori, T. Effect of $\gamma$-irradiation on the water soluble components of soybeans. Radiat. Phys. Chem. 1996, 47, 155-160. [CrossRef]

79. Choi, C.W.; Kim, S.C.; Hwang, S.S.; Choi, B.K.; Ahn, H.J.; Lee, M.Y.; Park, S.H.; Kim, S.K. Antioxidant activity and free radical scavenging capacity between Korean medicinal plants and flavonoids by assay-guided comparison. Plant Sci. 2002, 163, 1161-1168. [CrossRef] 
80. Rezk, A.A.; Al-Khayri, J.M.; Al-Bahrany, A.M.; El-Beltagi, H.S.; Mohamed, H.I. X-ray irradiation changes germination and biochemical analysis of two genotypes of okra (Hibiscus esculentus L.). J. Radiat. Res. Appl. Sci. 2019, 12, 393-402. [CrossRef]

81. Said-Al Ahl, H.A.H.; Sarhan, A.M.Z.; Dahab, A.D.M.A.; Abou-Zeid, E.-S.N.; Ali, M.S.; Naguib, N.Y. Bio-fertilizer and Gamma Radiation Influencing Flavonoids Content in Different Part of Dill Herb. Int. J. Life Sci. Eng. 2015, 1, 145-149. 